\title{
EUROPEAN TOURISM MANAGEMENT COMPETITIVENESS AND PECULIARITIES
}

\author{
Mihaela Vartolomei, Lecturer ${ }^{1}$
}

DOI: https://doi.org/10.31410/tmt.2018.473

\begin{abstract}
The scope of this research paper is to analyze the tourism sector and the tourism competitiveness in the frame of European Union (EU-28). The methodology of the paper is classic based on comparative analysis between EU-28 countries, using the analysis, the comparisons and the synthesis of available information. The main source of the data used is Eurostat database. The methodology of the paper is based on the data collected from numerous official, and semi-official published reports, research journals, newspaper reports, research articles, websites and works of the individual scholars: The Travel \& Tourism Competitiveness Report 2017 from World Economic Forum, Travel \& Tourism Economic Impact 2018 from World Travel \& Tourism Council. Finally, the paper concludes and aims recommendation and solution for tourism management in order to increase the European tourism efficiency and competitiveness facing worldwide major challenges regarding resources scarcity, climate change and world security.
\end{abstract}

Keywords: tourism management, competitiveness, sustainable development, comparative analysis, $E U-28$

\section{INTRODUCTION}

$\mathrm{T}$

The tourism activity has become a part of our daily life. The tourism management is the multi and interdisciplinary approach of all the activities that are related to the travel, hospitality and tourism industry, such as: the business management (finance, human resources, and marketing), the management theories and principles, and the tourism industry influence factors (motivation, environment, organization). The tourism sector is the most sensitive sector of the economics, reacting quickly to positive and negative events, also [1]. The effects of the tourism are multiple, both positive and negative ones. Hence, the positive peculiarities of the tourism concerns the economic progress opportunities (the development of tourism infrastructure, the development of transport infrastructure, the development of assurance sector, the development of collateral economic sectors such as the goods and services industry in accommodation, transport, food and drink, furniture, underwear, laundering, cleaning, security, information, technologies, communication, utility), the life relaxation and satisfaction it gives to travelers, it gives many kinds of opportunities, it increases the education level (by culture, or knowledge), it helps to understand other human races rising the tolerance among people. Thereby, the tourism industry is an important source of the incomes, economic development, foreign exchanges and sustainable development [2]. But, once the development of tourism activates, it has threats and negative peculiarities (terrorist attacks, natural adversities or catastrophes, climate change, pollution by increasing transport infrastructure). The new tourism is emerging, driven by the new consumers, the new technologies, the new production practices, the new management techniques, and the changes in the frame of the tourism industry conditions $[3,4]$.

The competitiveness is stimulus for the whole society, it is the source of the innovation and the value added in the management system. The key principles of the competitive success in the competitive strategies for the industry players and the tourism sector are: (1) put consumers first

\footnotetext{
Politehnica University of Timisoara, Management Departament, P-ta. Victoriei 2, 300006 Timişoara, Romania
} 
(the rule of the 'king consumer'); (2) be a leader in quality; (3) develop radical innovations; and (4) strengthen the player's strategic position within the industry's value chain [5].

The performance in tourism [6] field is appreciated using indicators that express the efficiency in economic activity relating to competitors, such as:

1. Service or company competitiveness,

2. Economic efficiency,

3. Economic efficacy,

4. Excellence.

At microeconomic level, a company prospers by getting more from its resources. Recall that economic efficiency is the situation in which company is on its production-possibilities frontier. Economic efficiency reflects the economic effect obtained using economic resources (doing things right). It can be calculated either dividing the outputs that can be produced (the production obtained and sold) to each and every set of specified inputs used (factors of production), or dividing the inputs used to the output. The tourism company is efficient if it reaches own qualitative targets (productivity, profitability, etc.) [7]. In Project Management, economic efficacy expresses the power to produce an economic effect, but doing the right things, and it reflects the realized or planned performances reported to the resources used. The tourism company is effective if it reaches own quantitative targets (related to sales, profit, etc.) [8]. The efficiency and the efficacy together represent the excellence (doing the right things right). The company activating in tourism is excellent if it realizes all quantitative and qualitative targets with efficiency and efficacy [9].

By all these means, competitiveness is a very complex term, being over the great influence of the capacity to be integrated into the market and the around environment. At microeconomic level, the scientific literature emphasizes many categories of competitiveness, from which of them it may be mentioned the following types: global competitiveness, financial competitiveness, trade competitiveness, human resources competitiveness, management competitiveness, technical competitiveness, organizational competitiveness.

Financial competitiveness is showed by indicators such as: the dimension of the global or average profit, cash flow, debt rate, financial productivity potential (own capital productivity), leverage ratio and potential, etc. Trade competitiveness is compound by the type of indicators: market share, sales, turnover, break-even point, life cycle place for each service, trade reputation, brand, trademark, trade flow, client fidelity, service constancy, publicity budget level, etc. Human resources competitiveness is referring to the skills, the qualification, the know-how, the (un)employment rate, the absenteeism rate, etc. Management competitiveness is designed by the manager profile (age, experience, knowledge, studies, education), the leadership capacity (bargaining capacity, leader ability and vocation), the degree of the team cohesion, etc. Technical competitiveness of tangible assets is illustrated by the equipment state (number of years in use, performances, depreciation degree), the technical advance, the research and development level, the automation level, the supply, the client relationship, the stock turnover velocity, etc. Organizational competitiveness is expressed by the organizational structure, the number of the hierarchical levels, the autonomy degree, the data flow, the decisions system, the degree services and employees integrated to inner objectives of the company, the way the objectives are achieved, the controlling system, the corporate social responsibility, etc. 
A greater performance for the competitiveness is showed by the labor productivity, labor cost, the degree the client requests are satisfied, the quality of the services, etc. The indicators related to the competitiveness are considered the sales, the turnover, the profit rate, the market share comparing with the results of the other companies on the travel and tourism market.

The base of the decisions and actions is the economic interest, the advantage resulted from an activity (action) reported with another alternative [10]. Thus, any decision is intuitive or consciously based on the relative (comparative) advantage theory, suggested by Adam Smith and grounded by David Ricardo. The comparative costs theory had become the base of the decision in more opportunities (alternatives) situation. It is saying about disposing comparative (relative) advantage reporting to other countries if the desired target is achieved with a lower opportunity cost [11].

An economic entity (a person or a country) have an absolute advantage when it produces goods with less resources or, reciprocally when from same resources it obtains more goods than others. Regarding the relative (comparative) advantage, the issue is more complex. For its determination it is necessary to determine the opportunity $\operatorname{cost}\left(\mathrm{C}_{\mathrm{o}}\right)$, it means the appreciation a country give to the relinquished alternative when it makes a choice.

The competitiveness is a necessary condition for the success on the market. Competitiveness is a very present question that requires to be approach both at microeconomic and macroeconomic level. The competing force of a company, product or service consists in competitive advantages and reflects the distinct competences it has in comparison with the companies, products or services they compete. The competitiveness of a company consists in the capacity to increase its incomes as a consequence of the increasing of the sales and profit margin in the market it competes, with the scope to obtain better places or to keep the present one [9].

\section{METHODOLOGY}

The methodology used in the present paper is classic using the analysis, the comparisons and the synthesis of available information. The main sources of the data used is Eurostat database. The methodology of the paper is based on the data collected from numerous official, and semi-official published reports, research journals, newspaper reports, research articles, websites and works of the individual scholars: The Travel \& Tourism Competitiveness Report 2017 from World Economic Forum, Travel \& Tourism Economic Impact 2018 from World Travel \& Tourism Council. The data are very poor from Eurostat database. From this reason, the methodology of the paper is based on the comparative analysis between European countries and consists in analyzing tourism activity, comparisons (between European countries) and synthesis of available information.

\section{SCIENTIFIC LITERATURE REVIEW OVER COMPETITIVENESS}

Economic literature survey shows many approaches of competitiveness concept in empirical studies, this term being the most used concept in economics without a generally accepted definition, even if Krugman [12] argued that economists do not use this word, but he claimed the competitivity to be another way to define productivity: the ability of a nation to improve its living level, the standard of living, a high employment on a sustainable basis, depending on the ability to increase the productivity level $[13,14]$. Nevertheless, the competitiveness concept was described to be related to the market mechanism: individual product/service, company, industry, economic sector, or region [15]. 
Hence, on one hand, at macroeconomics level, Bobba et al mentioned that competitiveness is the ability of economy, regions and companies to generate wealth. Furthermore, the competitiveness is approach as the capacity for the industry to produce and sell the goods at an attractive price-quality report [16]. The competitiveness of a country is measured by the degree the goods or services produced are able to face international markets [17].

On the other hand, at microeconomics level, Ajitabh and Momaya [18] stated that the competitiveness of a firm is represented by its share in the competitive market. Chao-Hung, Li-Chang [19] underlined that the competitiveness of the firm represents its economic strength against the rivals in the market. The competitiveness of a company is referring to adapt its products to the market and competition requirements, in terms of product range, quality, price with the $\mathrm{s}$ market methods and rules [18]. Buckley et al. [20] supplied the idea that the competitiveness of a firm is related to the capacity to obtain products and services of upper quality and lower costs than the other in the market at national and international level, and the competitiveness express the performance of a company regarding the profit and its ability to provide superior returns to its owners. Tyson D'Andrea [21] formulated the competitiveness is the ability to produce goods and services that meet the test of international competition while the citizens meet a higher and sustainable standard of living. The World Economic Forum (WEF) [22] defined the competitiveness as the ability of a country to achieve sustained high rates of growth in GDP per capita.

\section{EMPIRICAL STUDY AND DISCUSSION ABOUT TOURISM INDUSTRY IN EU-28}

Scientific literature distinguishes as main competitiveness components the classical factors and essential factors. The first category is compounded by quantitative factors (the price, the quality, the relationship price/quality, the cost, the profit, the ratio cost/profit, the volume of the sales, the volume of the receipts) and qualitative factors (the scale economy, the technology, the management, the strategy). The quality and the price are the most highlighted factors of the competitiveness in tourism and travel field: the same service offered but with less amount of money or the same amount of money required for a service which has a better quality. The relationship between cost and quality is eliminatory. The second main factor of competitivity is relationship between cost and profit. From this point of view, a company in travel and tourism field is competitive if it realizes high profit with less cost. On the other hand, the dimension of the sales defines the size of the company. But the previous mentioned factors are controlled by factors that express the volume of the output (the scale economy, the technology, the management, the strategy). The volume of the output is strictly depending on the average cost in short run terms. The current management must be adapted to the output volume and to the technology used. Thus, the competitiveness strategy determines the volume of the output and the selected technology.

The essential factors of competitiveness include aspects about the last work reused, applied innovation, harmony degree, the capacity to identify and promote the value. The more is the company ability to use last work (in terms of fix capital, tangible assets, intangible assets, educated and trained labor force) the more is the possibility of the company to produce new value added, but taking into account the newest and most developed technologies. At macroeconomic level, one competitiveness factor is the stability of the values system, represented by the stability of the property, the stability of the judicial system, contractual discipline, symmetry of relations between asymmetric partners and others. At world level, the experience shows the fact the applied innovation (innovation in all fields: technological, management, communication, organization, interpersonal relationships structure) is the greatest competitive advantage. 
Figure no.1 presents the case regarding the travelers (one night or over) for personal purposes (expressed by the number of the tourists as the share of the total population) for the period of time 2012 till 2017, from the data availability and accessibility reason (Eurostat supply data regarding this indicator starting just with the year 2012 till 2017, except Luxembourg which didn't published data for 2017).

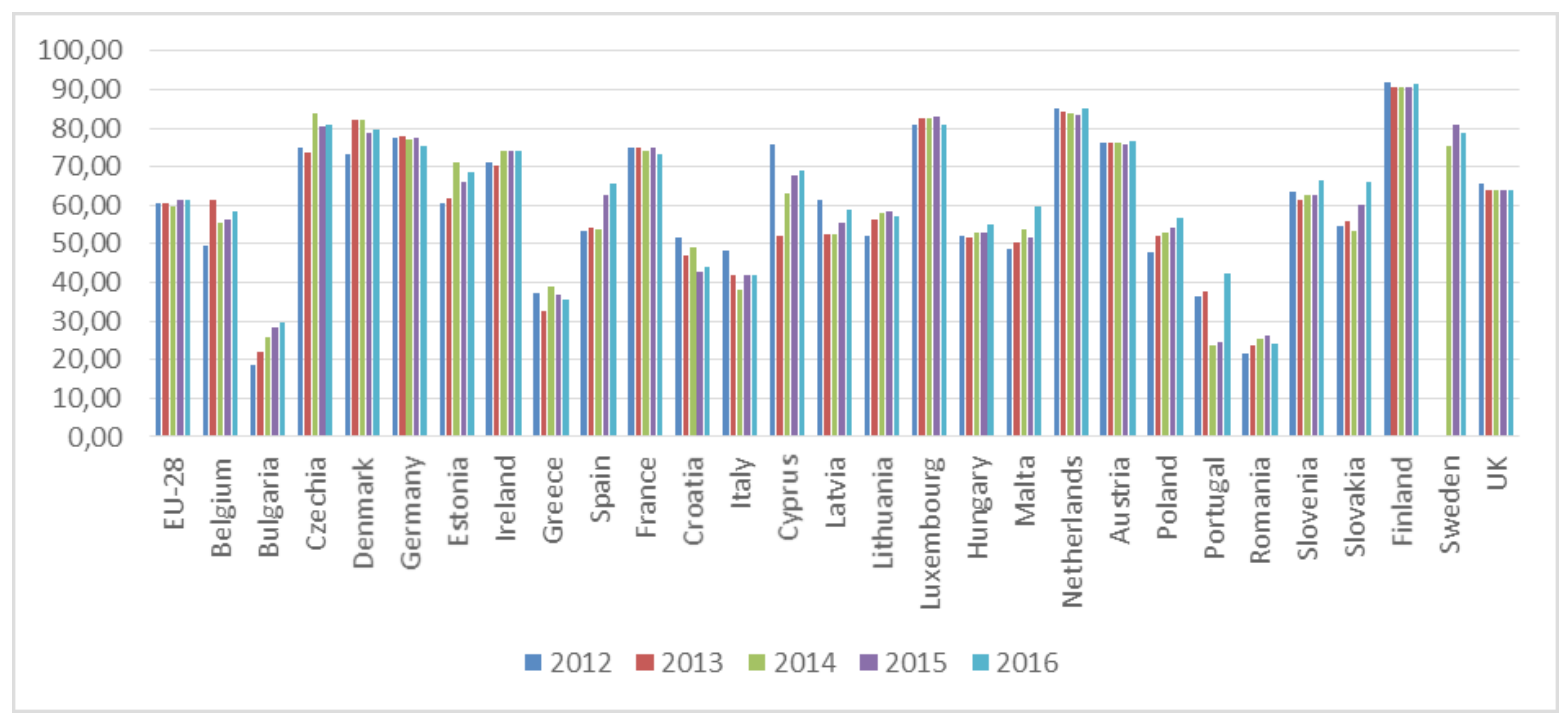

Figure 1: Participation in tourism for personal purposes (tourists as share of total population) Sources: by author using Eurostat data

Hence, it can be easily noticed that citizens from Romania, Bulgaria followed by Portugal, and Greece participate to the tourism industry the least comparing with the average EU-28 countries, and the citizens from Finland, Netherland, Denmark, Germany, Luxembourg registered the highest level in the EU-28, being more than double. For instance, the gap between the less (Bulgaria) and the highest (Finland) result in 2012 is 73.28 (computed as difference between figures), and this means the index (the ratio between the highest and the less result) is $490 \%$. In 2013 the gap between the less (Bulgaria) and the highest (Finland) was 68.69 and the index was $412 \%$. In 2014 the gap between the less (Portugal) and the highest (Finland) was 66.88 and the index was 380\%. In 2015 the gap between the less (Portugal) and the highest (Finland) was 66.26 and the index was 372\%. In 2016 the gap between the less (Romania) and the highest (Finland) was 67.44. In 2017 the gap between the less (Romania) and the highest (Finland) was 64.57 and the index was $342 \%$. We can notice that the performers are northern countries and the less are central and southern European countries.

The tourism is part of the service economy and the gross domestic product (GDP). The tourism industry is tightly linked with other economic areas: service, transportation means, the combustible use, the norms of environment protection, the safety and the security services. For this reason, we will study the GDP level inside EU (figure 2). We can notice again that the performers regarding the gross domestic product are developed countries (from north and central Europe) and the less are central European countries (former communist countries). 


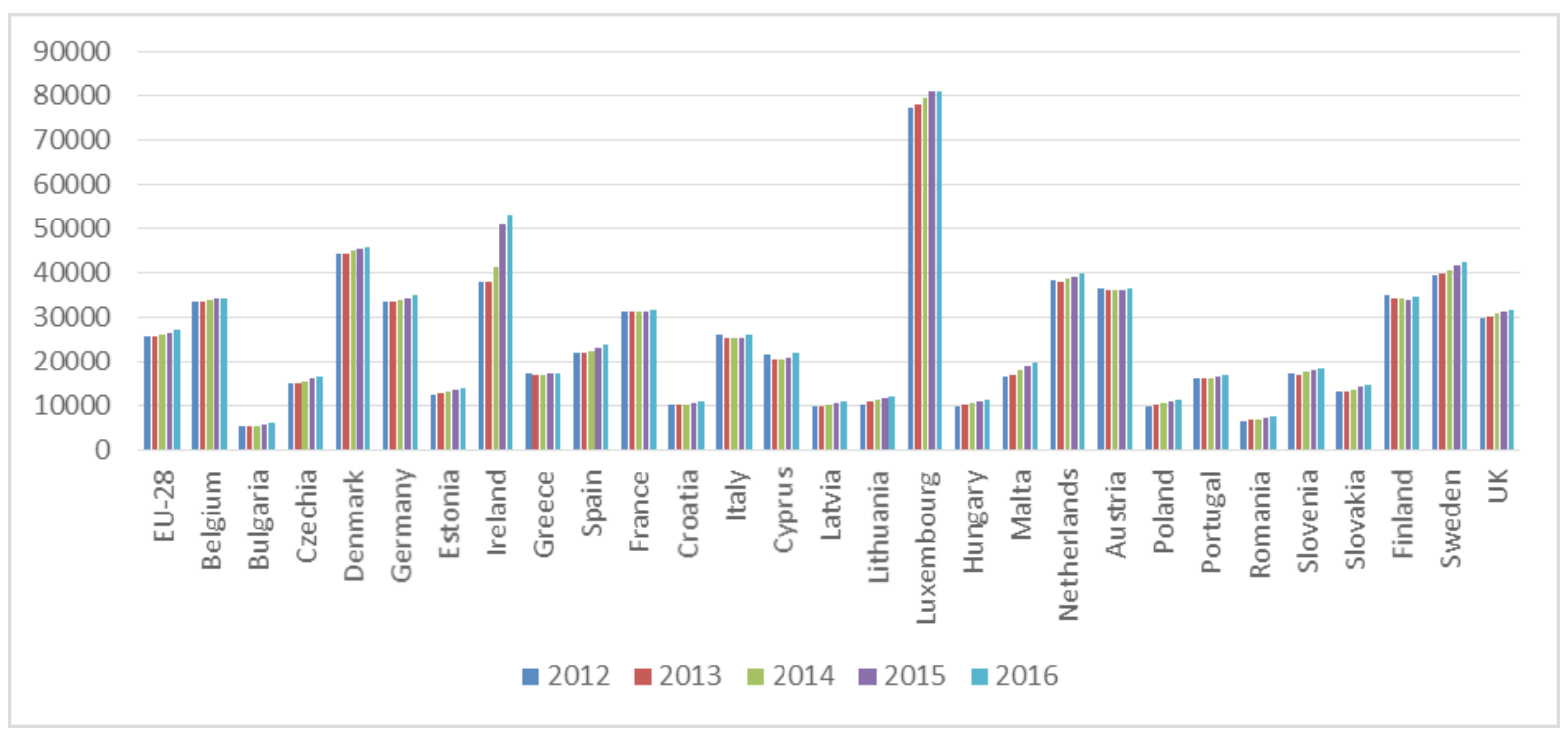

Figure 2: Real GDP per capita

Sources: by author using Eurostat data

The best results regarding the GDP (expressed in euro per capita) of the EU-28 countries for 2012 - 2016 period of time are registered by Luxembourg, Denmark, Netherlands and the lowest results are obtained by Bulgaria, Romania. Finland and Germany registered GDP up from EU28 average (figure 3). Hence, Luxembourg, Denmark are the performers and Bulgaria, Romania are the last both in tourism participation and in GDP per capita.

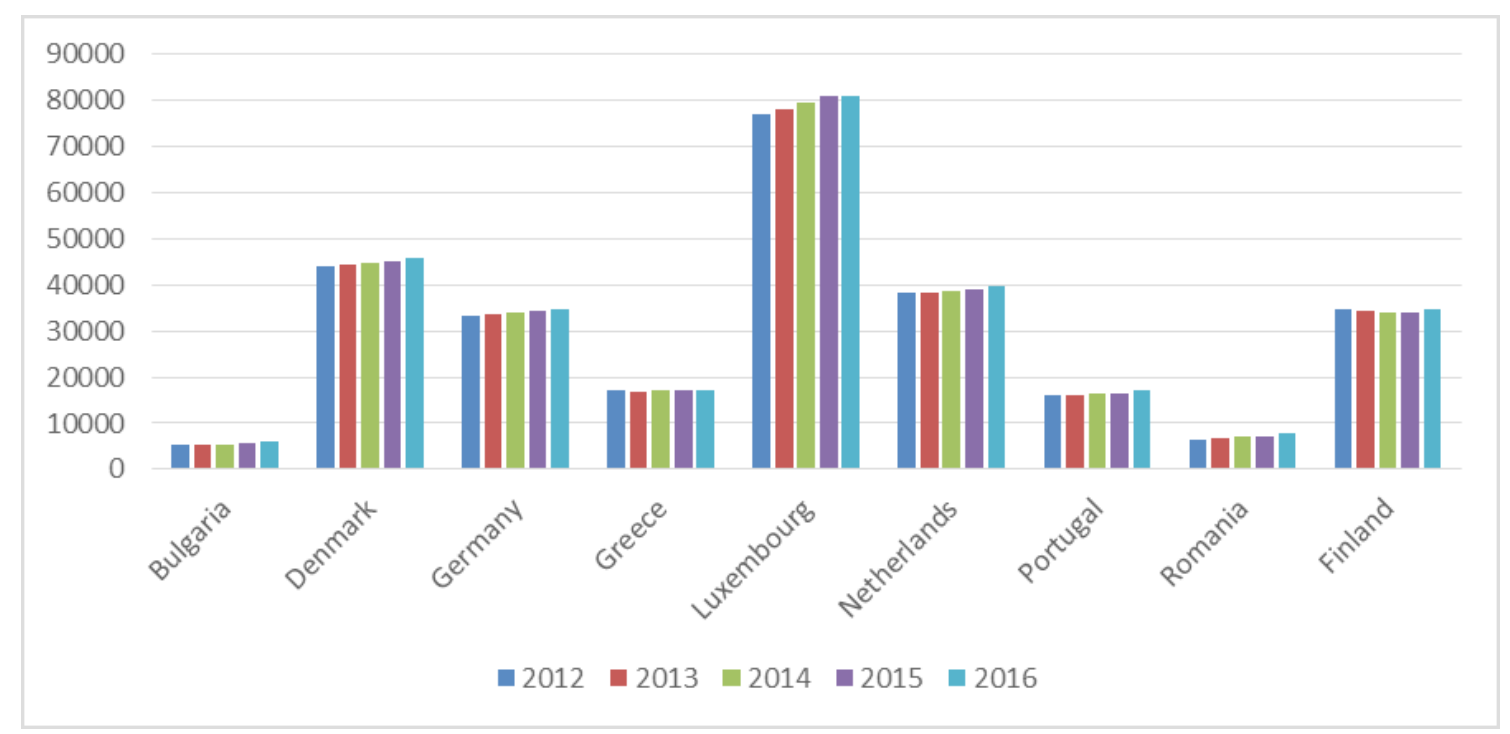

Figure 3: Real GDP per capita for the best performing in tourism participation Sources: by author using Eurostat data

Figure 4 shows the total civil research and development appropriations as percentage of the gross domestic product for the same period of time. The best performers countries are Denmark and Finland, followed by Austria (developed countries) and the weakest performers countries are Bulgaria, Romania, Latvia (former communist regime). Also, Malta registered weak results. 


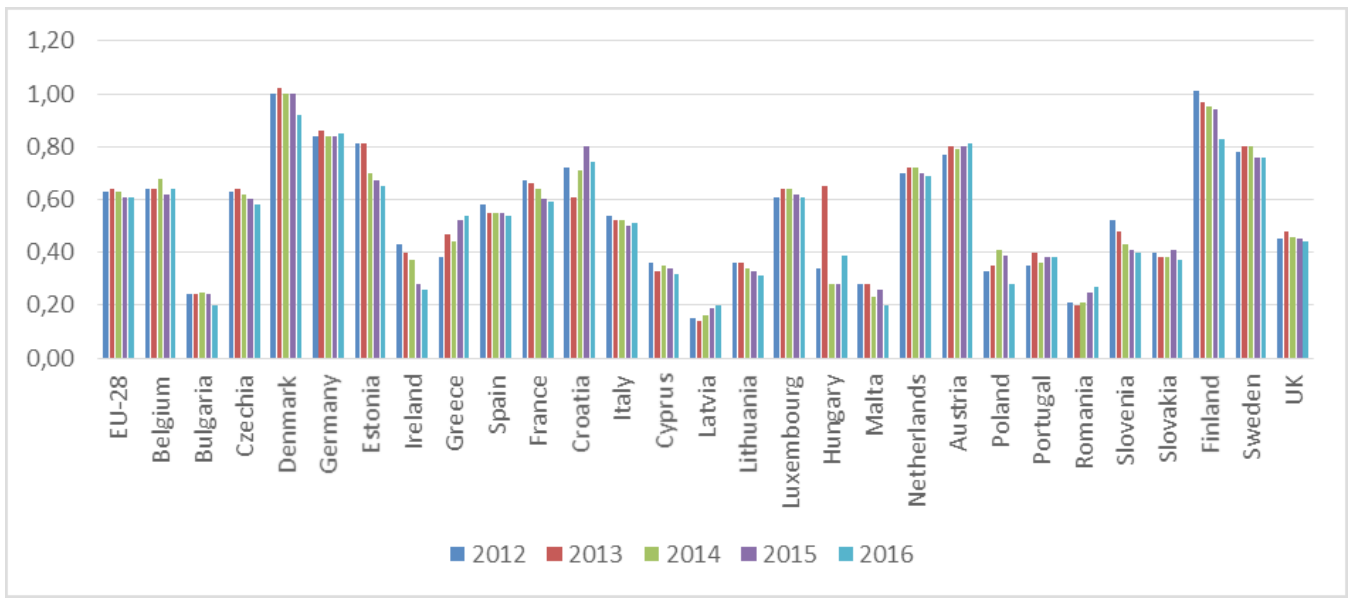

Figure 4: Share of expenditure with research and development in GDP (in \%) Sources: by author using Eurostat data

The transport, telecommunication and other infrastructures findings (expressed in million euro) are caught in figure 5, and expressed in euro/habitant are illustrated in figure 6 (the unavailable data are eliminated: Lithuania).

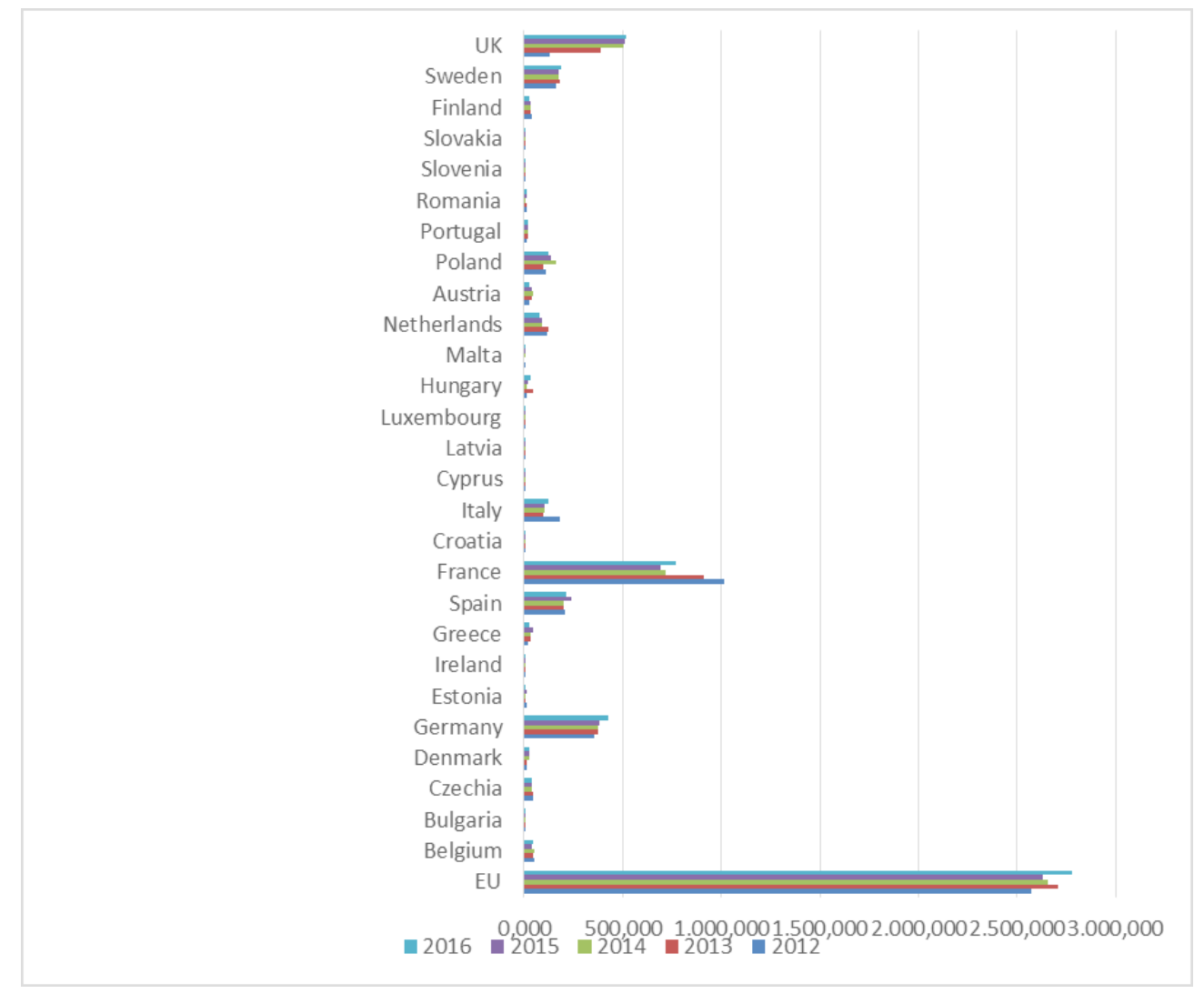

Figure 5: Transport, telecommunication and other infrastructures (million euro) Sources: by author using Eurostat data 


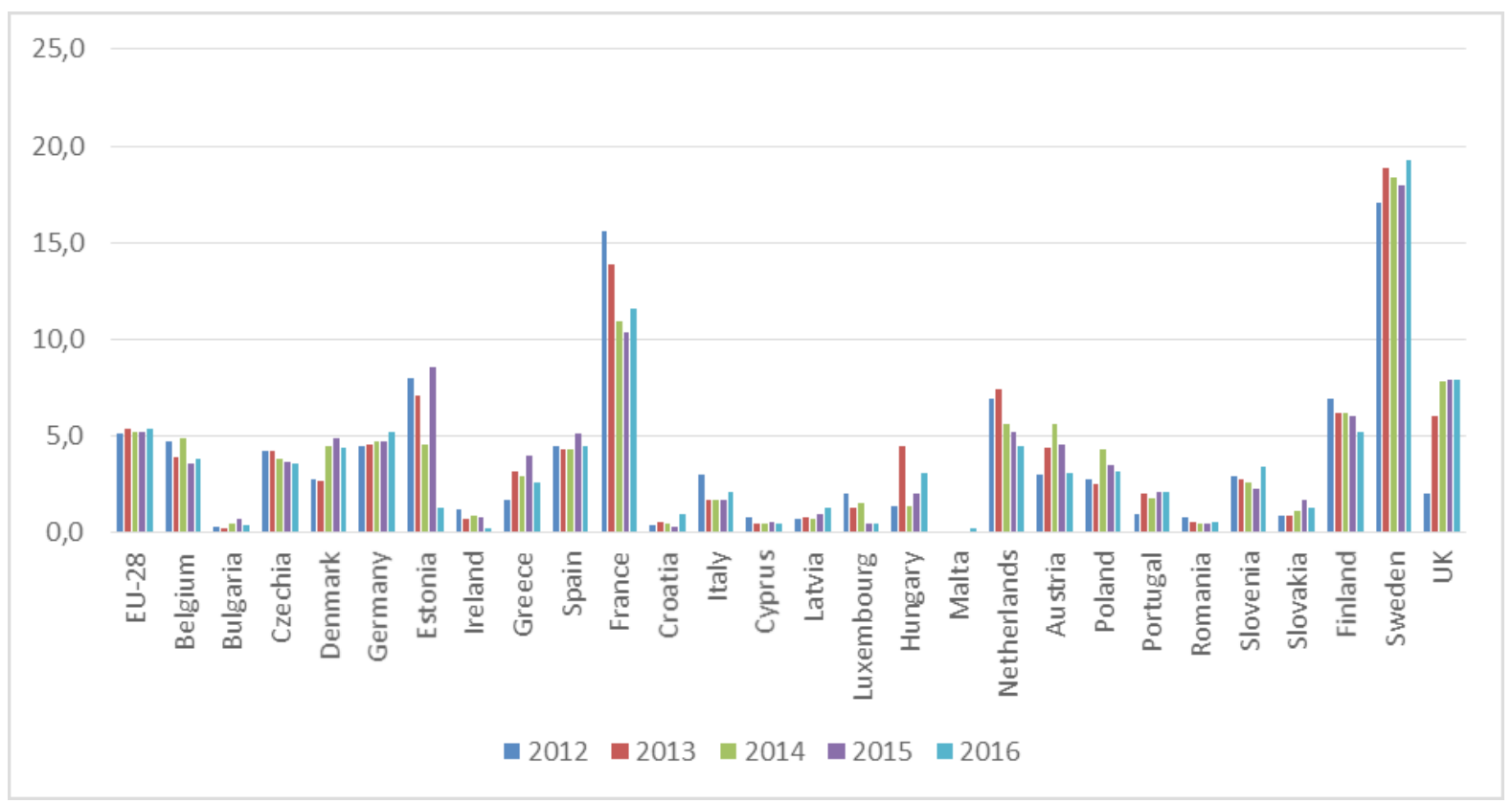

Figure 6: Transport, telecommunication and other infrastructures (in euro/habitant) Sources: by author using Eurostat data

Figure 7 shows the transport, telecommunication and other infrastructure as percentage in the gross domestic product (GDP). The unavailable data are eliminated from the study (Lithuania). It is obvious that the countries with high allocation in transport, telecommunication and other infrastructure from Government Budget Appropriation on Research and Development (GBAORD), even it is expressed in euro per habitant or in percentage of GDP, are France, Sweden in the chosen period of time, but also Denmark, Germany, Netherlands, Finland, United Kingdom registered high findings (around the average of EU-28). The countries with modest results are Bulgaria, Romania, Malta.

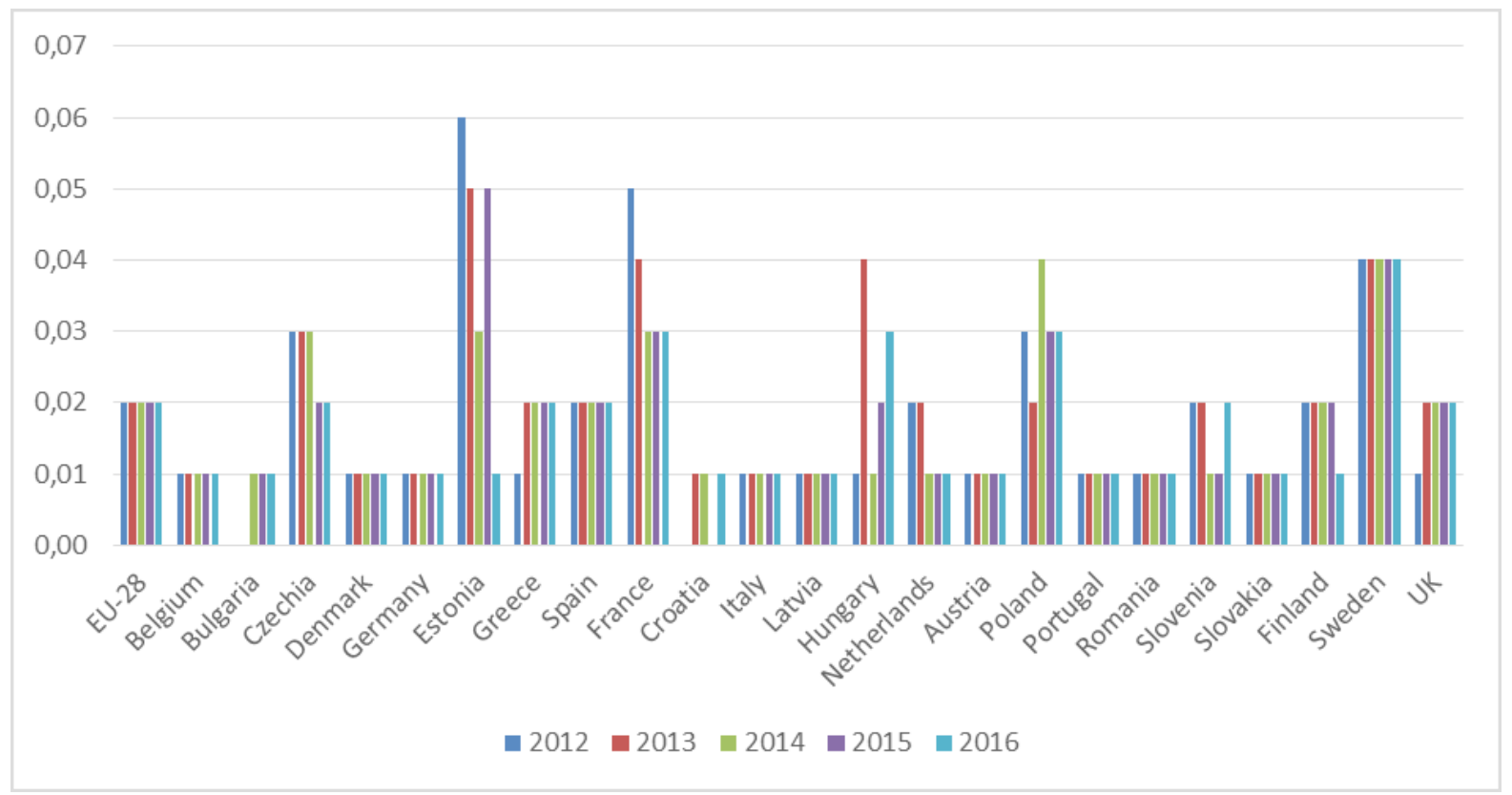

Figure 7: Transport, telecommunication and other infrastructures (in percentage of GDP) Sources: by author using Eurostat data 
The index for the share of expenditure with R\&D in GDP (figure 8) is drawn in figure and is related to final year (2016) and initial year in the present study (2012). All countries registered growth between 0.15 (Latvia) and 1.1 (Finland).

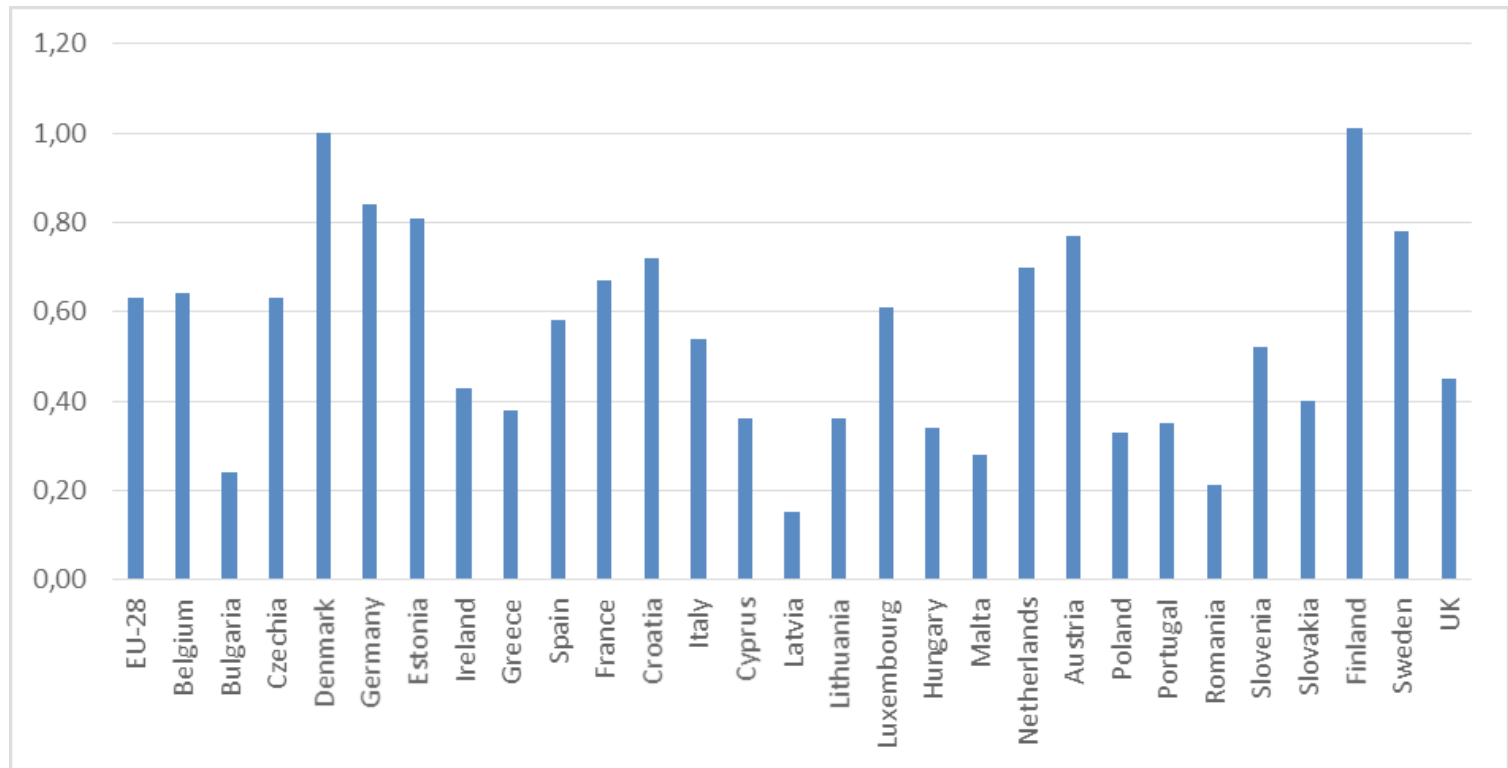

Figure 8: Index of R\&D expenditure share in GDP, 2016/2012 (in \%)

Sources: by author using Eurostat data

The number of the accommodation establishments (short-term accommodation facilities for the tourists that pay that service) in EU-28 (figure 9 show the index of the accommodation establishments) generally have increased in the 2012-2016 period of time, but spectacular increase registered Portugal (1.78\%), followed far away by Belgium (1.68\%), Lithuania (1.64\%), Croatia (1.44\%), Romania (1.37\%), Netherlands (1.31\%) and Bulgaria (1.21\%) and Estonia (1.17\%). The smallest result was registered in Ireland $(0.39 \%)$.

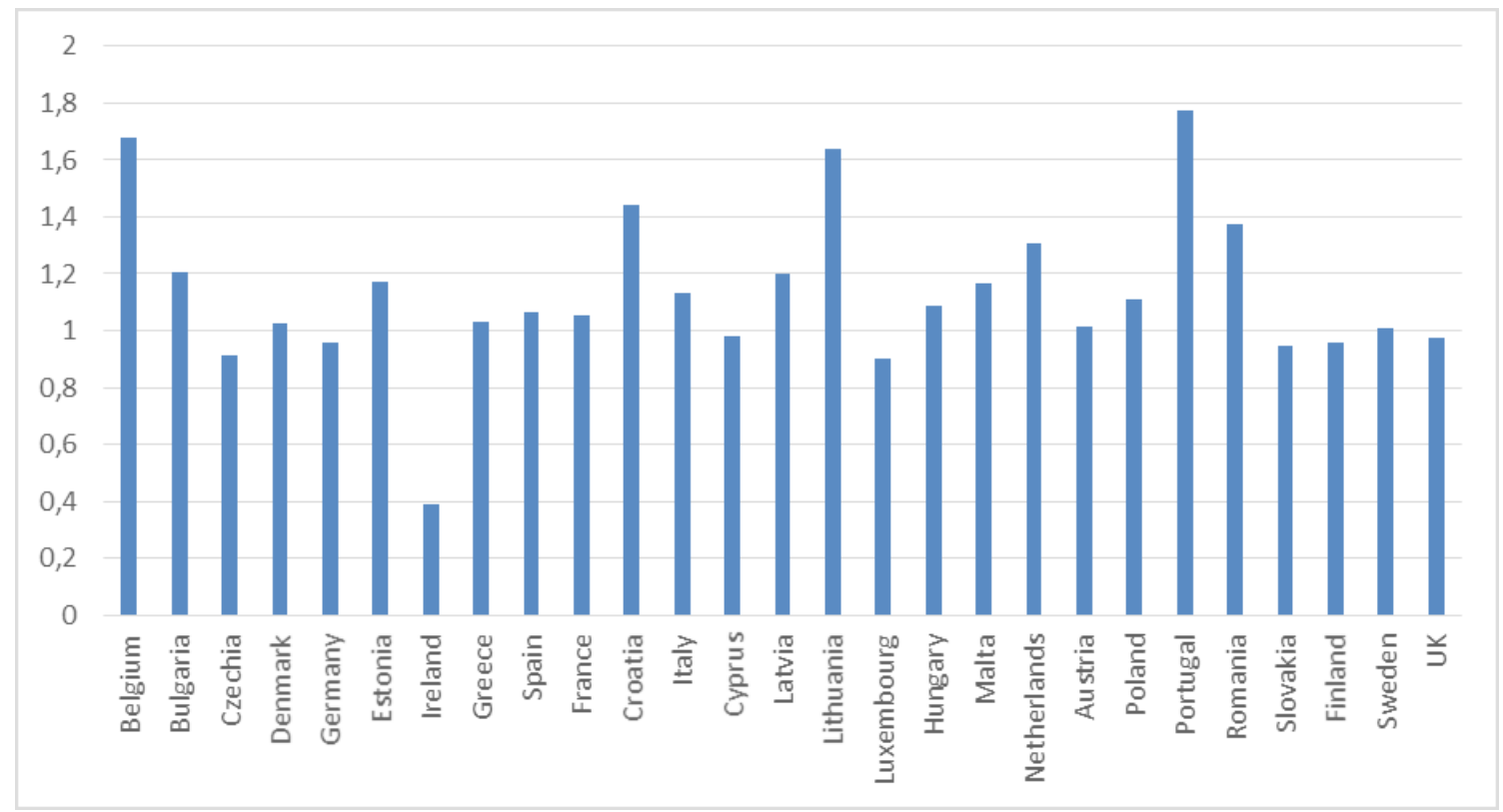

Figure 9: Index of accommodation establishments (2016/2012)

Sources: by author using Eurostat data 
The following figures are related to the European Union tourism industry: the number of travels, tours operator reservation service and related activities expressed in the number of the activities (figure 10), the number of the person employed (figure 11).

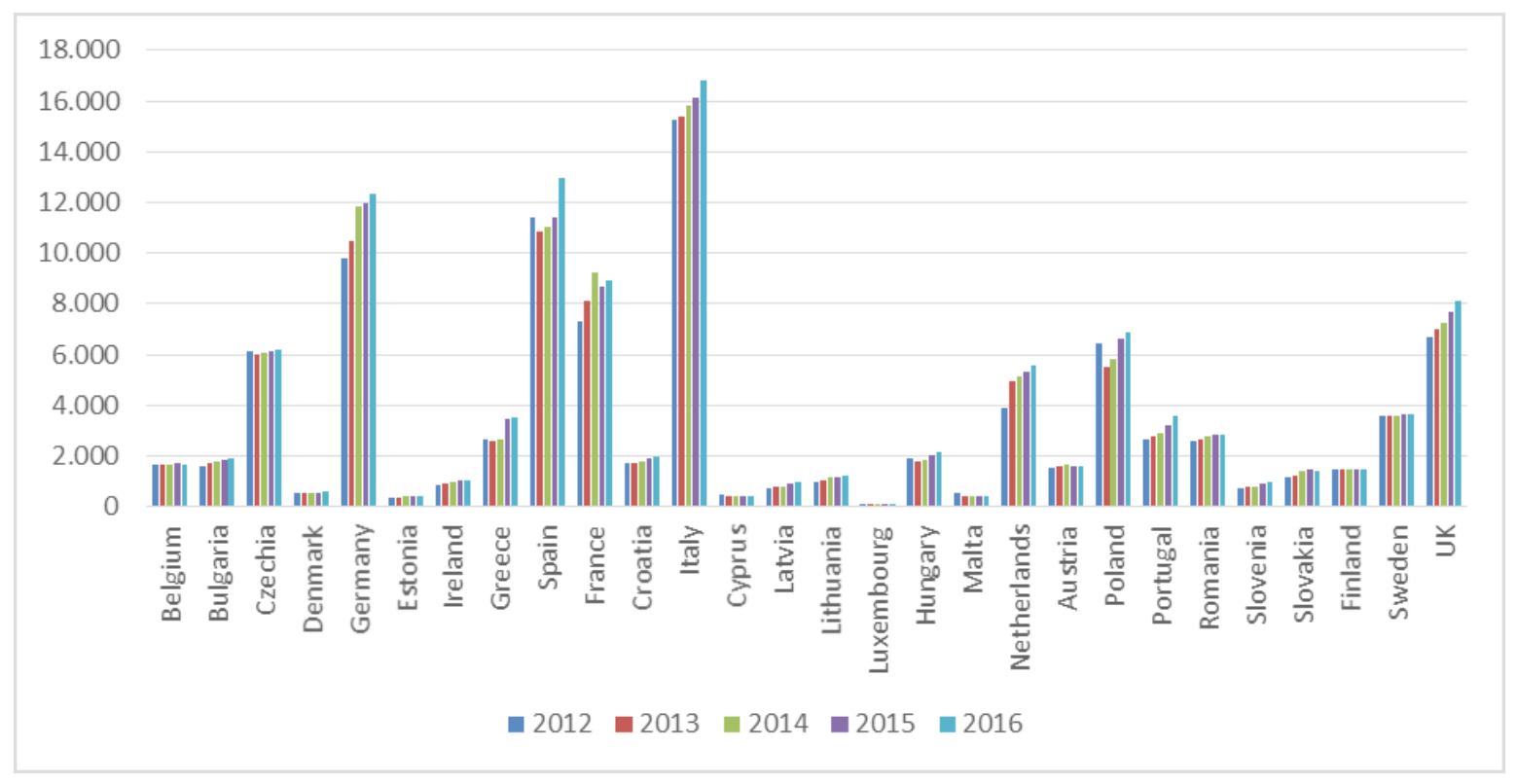

Figure 10: Tourism activities

Sources: by author using Eurostat data

Italy, Spain and Germany registered the highest results in the number of the tourism activities expressed in the number of the travel agency, the number of the tours operator reservation and related tourism activities, and Luxembourg registered the less result.

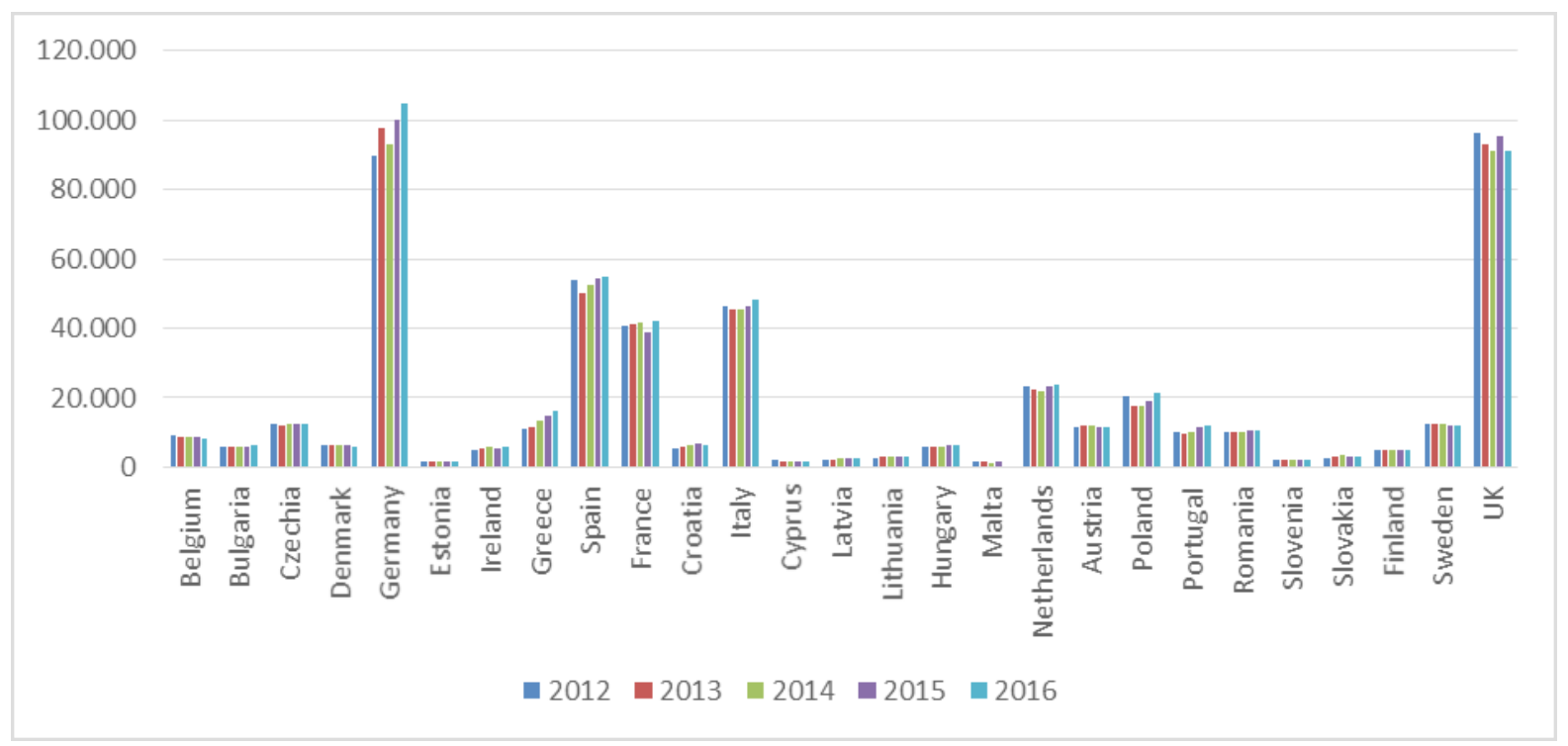

Figure 11: Persons employed in tourism entities (numbers)

Sources: by author using Eurostat data

Germany and United Kingdom registered the highest results in the number of the persons employed and Malta, Cyprus, Baltic countries (Estonia, Latvia, Lithuania), Slovenia, Slovakia registered the less result. 


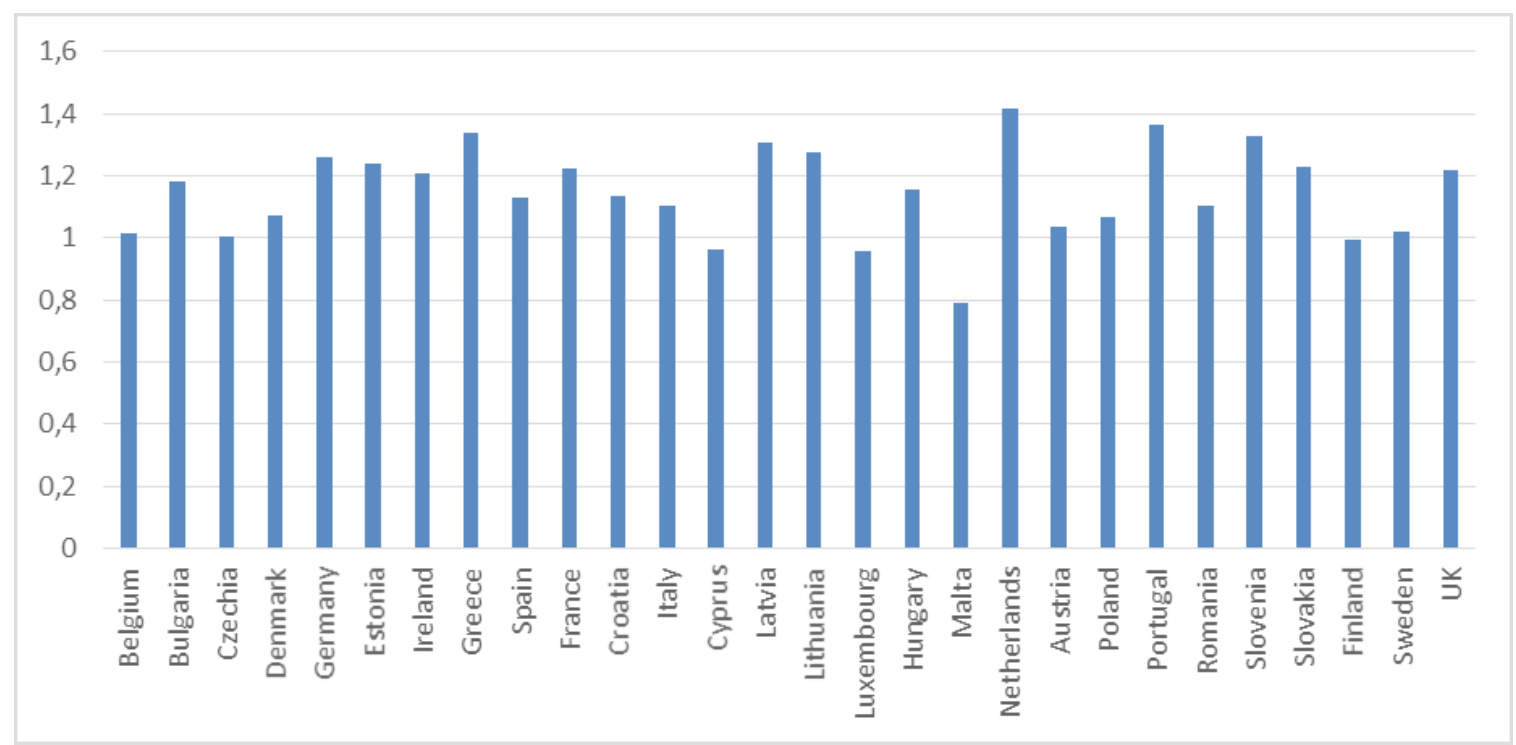

Figure 12: Index for number of tourism entities (2016/2012)

Sources: by author using Eurostat data

According to Eurostat database, the number of companies in tourism field (travel agencies, tour operator reservation service and related activities) in the period of time 2012-2016 increased in all 28 actual EU countries. The figure 12 shows the index for the number of travel agency, tour operator reservation service and related activities computed as the ratio between the value in 2016 and the value in 2012. The index is positive for all EU-28 countries. Netherlands registered the great rise in the number of the tourism entities and Malta registered the less increase.

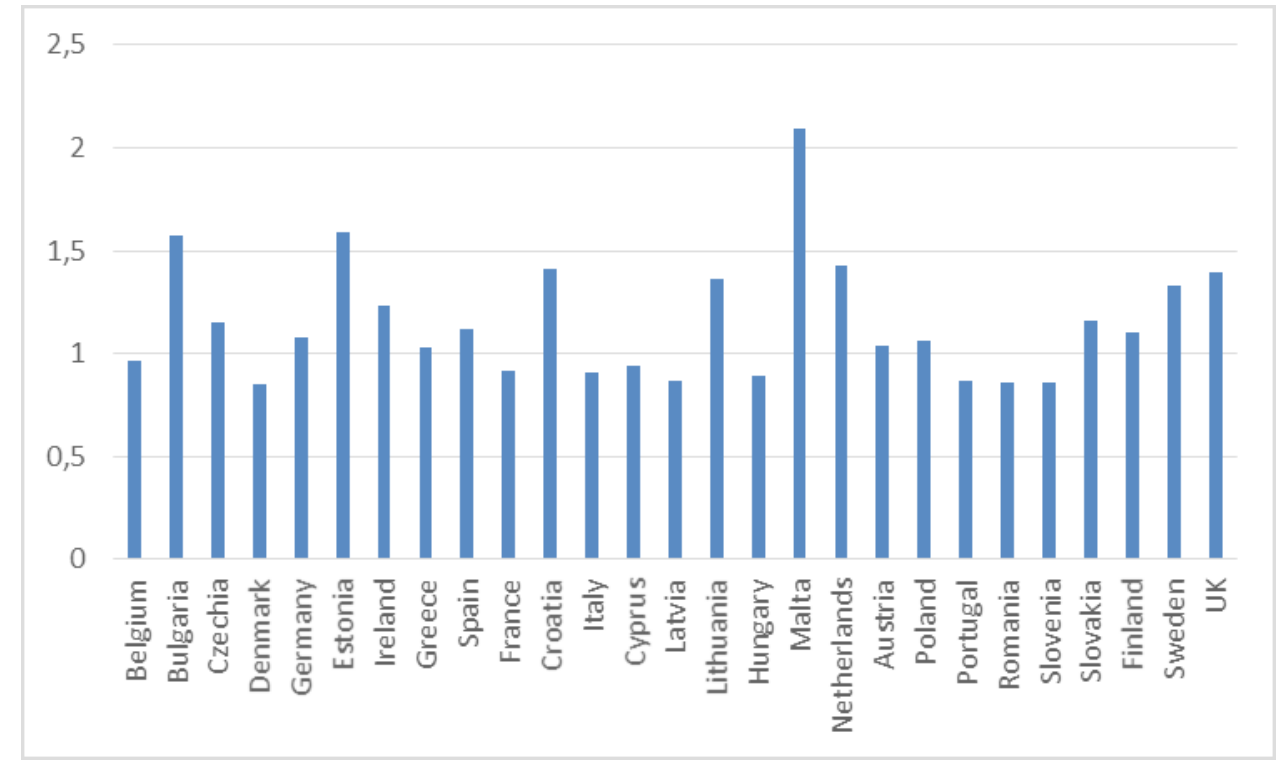

Figure 13: Index for turnover per person employed (2016/2012) Sources: by author using Eurostat data

The evolution of the turnover per person employed expressed in thousand euro per person is computed as the ratio between the value in 2016 and the value in 2012 and it is shown in the figure 13. The best performances are obtained by Malta with $209.57 \%$, Estonia with $159,19 \%$, and Bulgaria with $157.5 \%$. The lowest results are obtained by Denmark with $85.23 \%$, Romania with $85.56 \%$, and Slovenia with $85.65 \%$. The findings for Luxembourg are not available. 


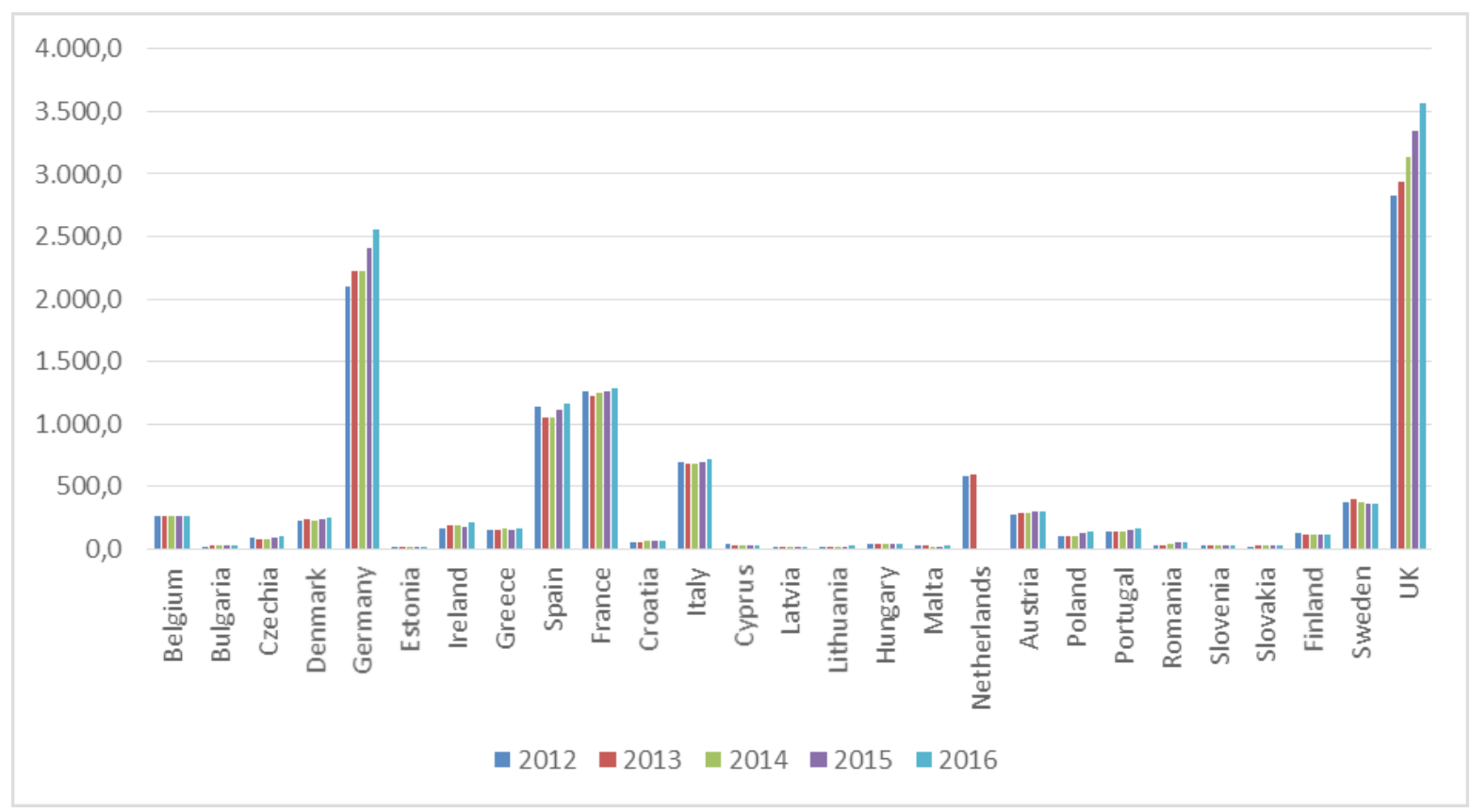

Figure 14: Index for turnover per person employed (2016/2012)

Sources: by author using Eurostat data

The evolution of the wages and the salaries expressed in million euro in the travel agency for 2012-2016 are shown in the figure 14. The biggest salaries are registered in Germany and United Kingdom and the smallest salaries are registered by central and eastern European countries (Slovenia, Slovakia, Bulgaria, Romania, Latvia, Estonia Lithuania, Hungary) and Malta and Cyprus. The findings for Luxembourg are not available.

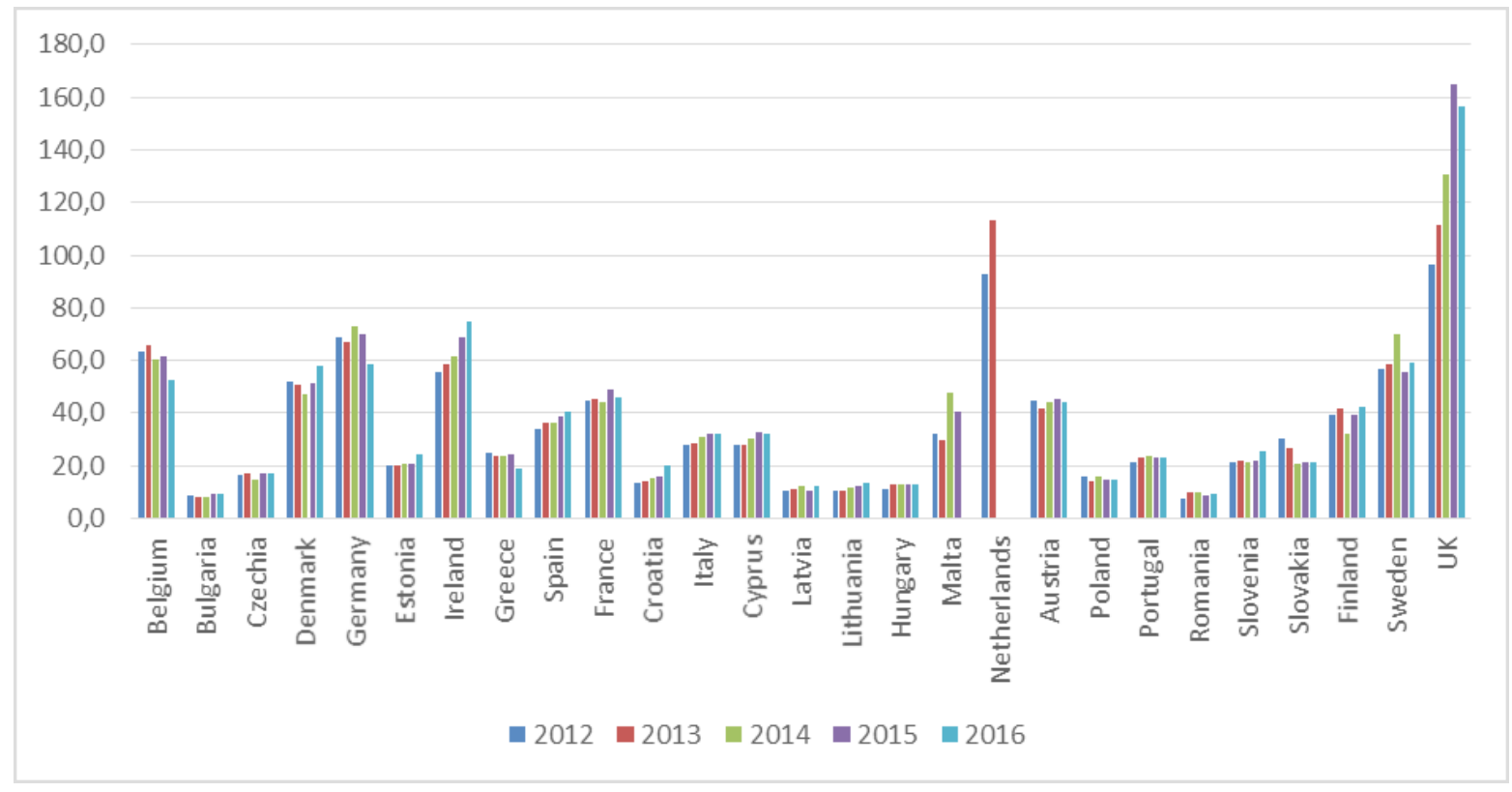

Figure 15: Apparent labour productivity (2016/2012)

Sources: by author using Eurostat data

The apparent labor productivity (figure 15) calculated as the ratio between the gross value added and the person employed is expressed in thousand euro. 


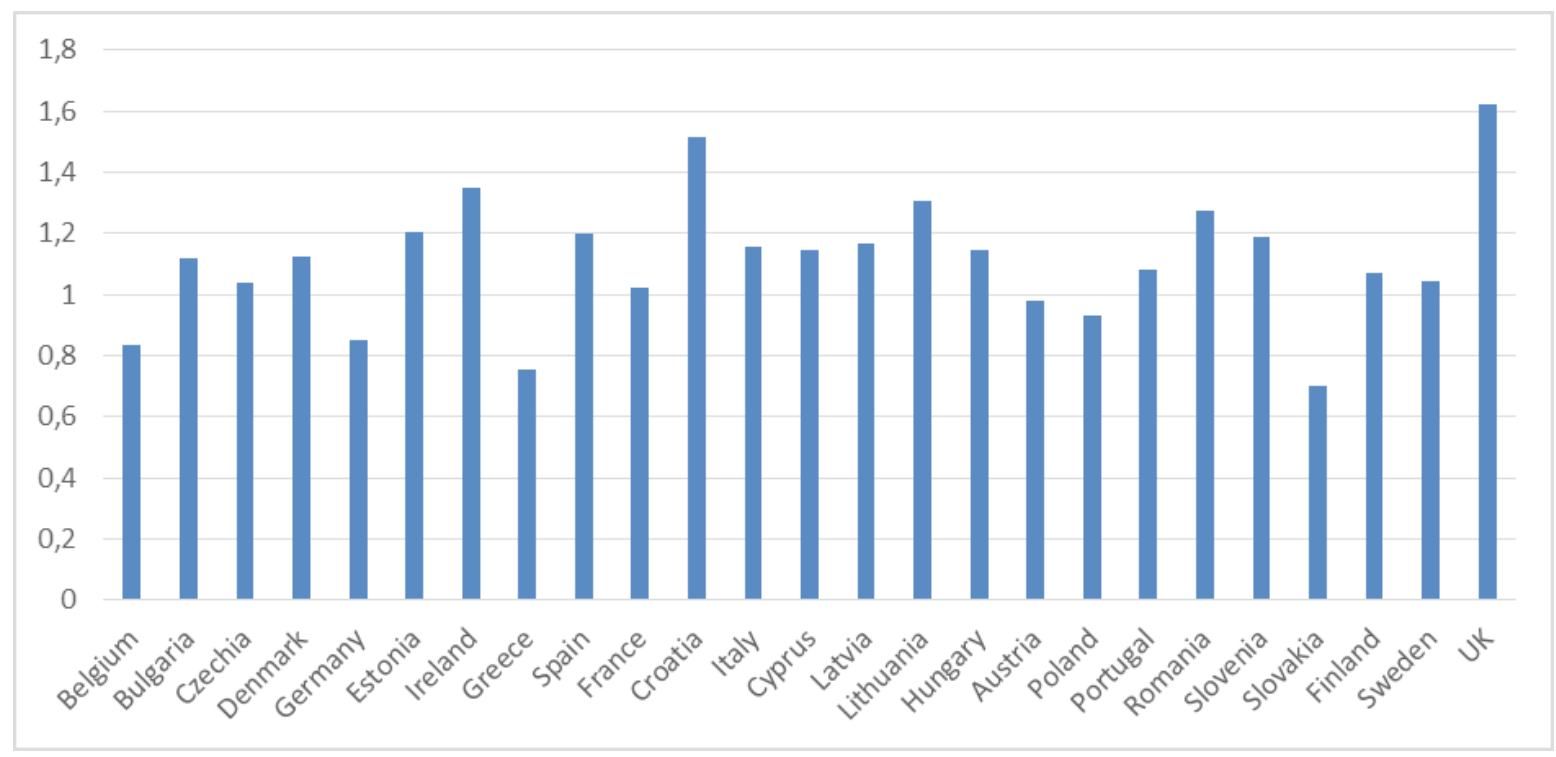

Figure 16: Index of labor productivity (2016/2012)

Sources: by author using Eurostat data

The index of the labor productivity (figure 16) is computed as the ratio between the value in 2016 and the value in 2012. The biggest values are registered by United Kingdom (162\%) and Croatia (151\%) and the opposite places are occupied by Slovakia (70\%) and Greece (75\%). Luxemburg, Malta, Netherlands have no available data.

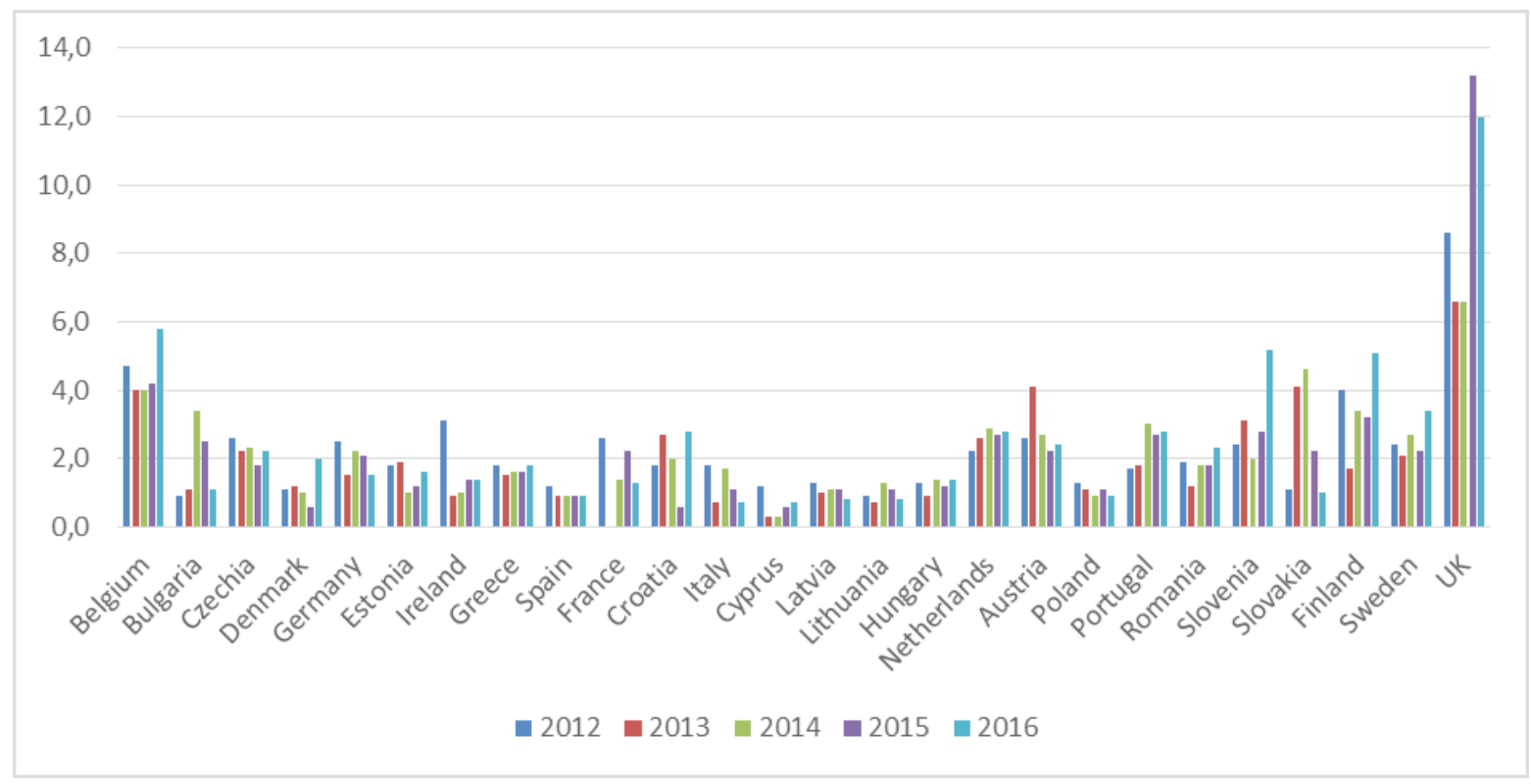

Figure 17: Investment per person employed for 2016-2012 (million euro)

Sources: by author using Eurostat data

The case of the investment per person employed expressed in million euro is illustrated in the figure 17. Far away, United Kingdom registered the biggest value and Cyprus the less value. 


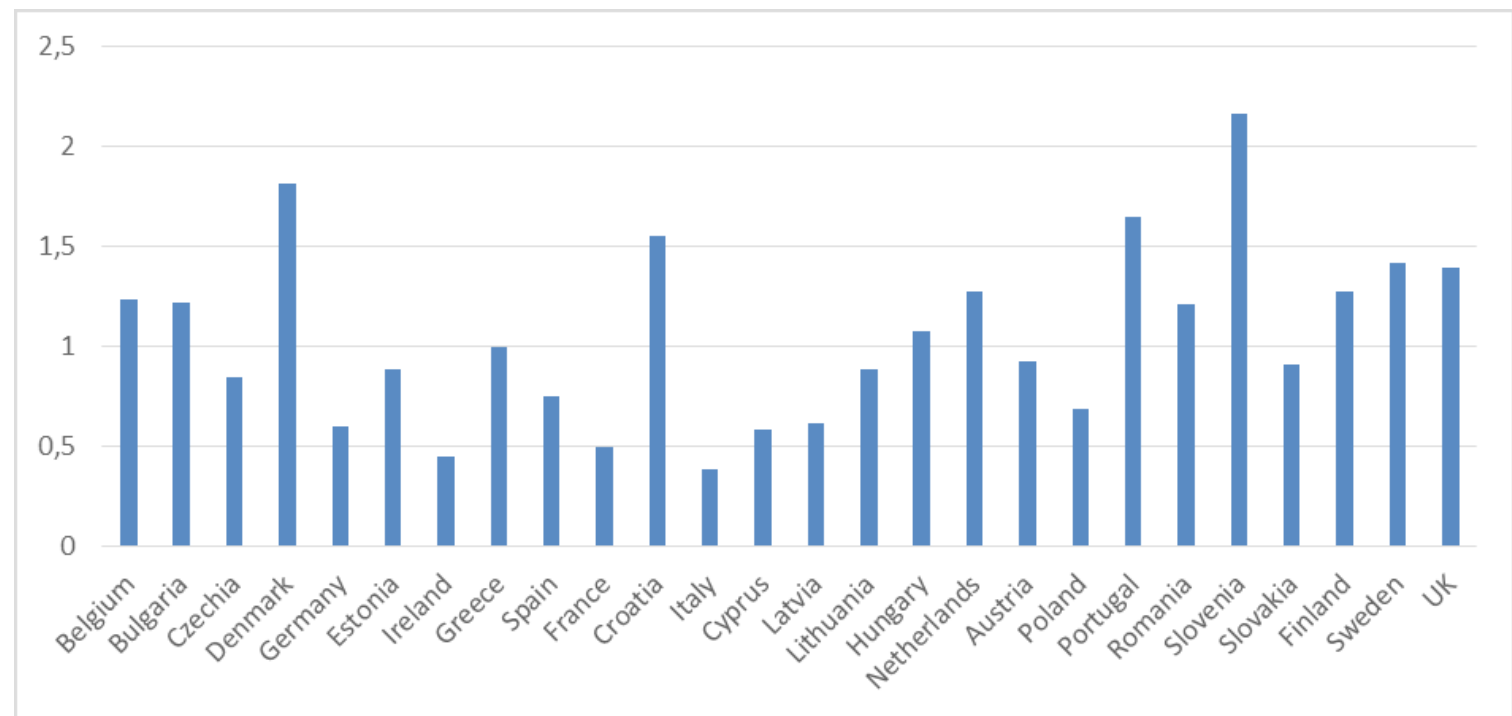

Figure 18: Index of investment per person employed (2016/2012)

Sources: by author using Eurostat data

The index of the investment per person employed expressed in percent is the value expressed in million euro registered in the year 2016 reported to the value in 2012, and it is illustrated in the figure 18. The index increased very much in Slovenia (217\%) and Denmark (182\%), and it registered a smaller increase in Italy (39\%) and Ireland (45\%).

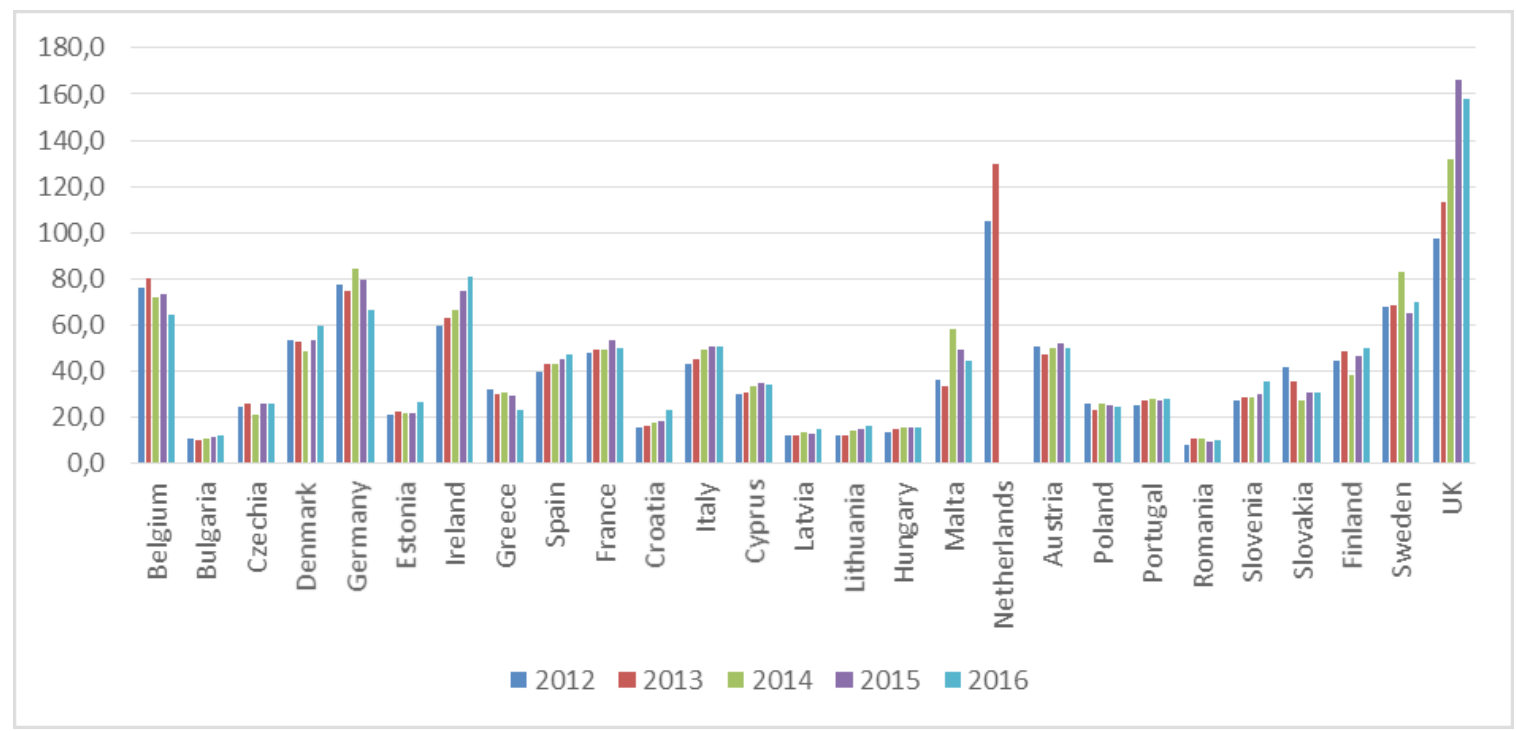

Figure 19: Gross value added per employee for 2012-2016 (thousand euro)

Sources: by author using Eurostat data

The gross value added per employee (expressed in thousand euro) is shown in the figure 19. United Kingdom and Netherlands registered the biggest value and Romania and Bulgaria registered the less value.

The index of the gross value added per employee expressed in thousand euro is computed as the ratio between the value in 2016 and the value in 2012 (figure 20). It is noticed that United Kingdom (162\%) and Croatia (150\%) have the biggest result. Greece (71\%) and Slovakia (72\%) are at the opposite positions. Data for Luxembourg and Netherlands are not available. 


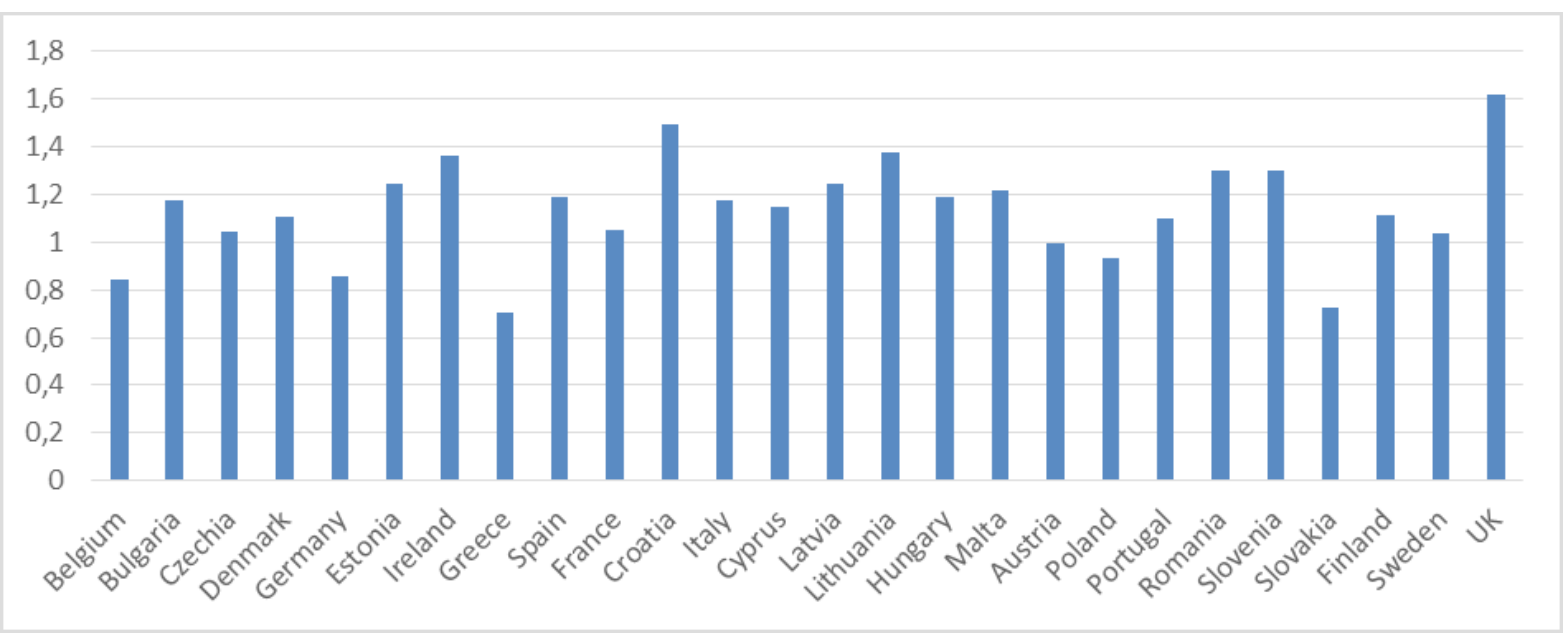

Figure 20: Index of gross value added per employee

Sources: by author using Eurostat data

According to the report of the World Economic Forum (an independent international comparator of national performance in tourism) for 2017 (Travel \& Tourism Competitiveness Report TTCR) the region with the better Travel \& Tourism Competitiveness Index (TTCI) is Europe and Eurasia EU-28 with five countries (Spain, France, Germany, United Kingdom, Italy) in the top 10. The Travel \& Tourism Competitiveness Index (TTCI) scored from 1 (the less performance) to 6 (the best performance), is related in fact more to the attractiveness in developing business in the travel and tourism industry rather than to the attractiveness of the country as tourism destination [23].

In 2017, the Travel \& Tourism Competitiveness Index ranked Spain on the $1^{\text {st }}$ global place (global rank) out of 136 countries around the world with a score of 5.43 points, France on the $2^{\text {nd }}$ global place with a score of 5.32, and Germany on the $3^{\text {rd }}$ place with the score of 5.28 points. The figure 21 illustrates the evolution of the rank for EU-28 during 2007 till 2017.

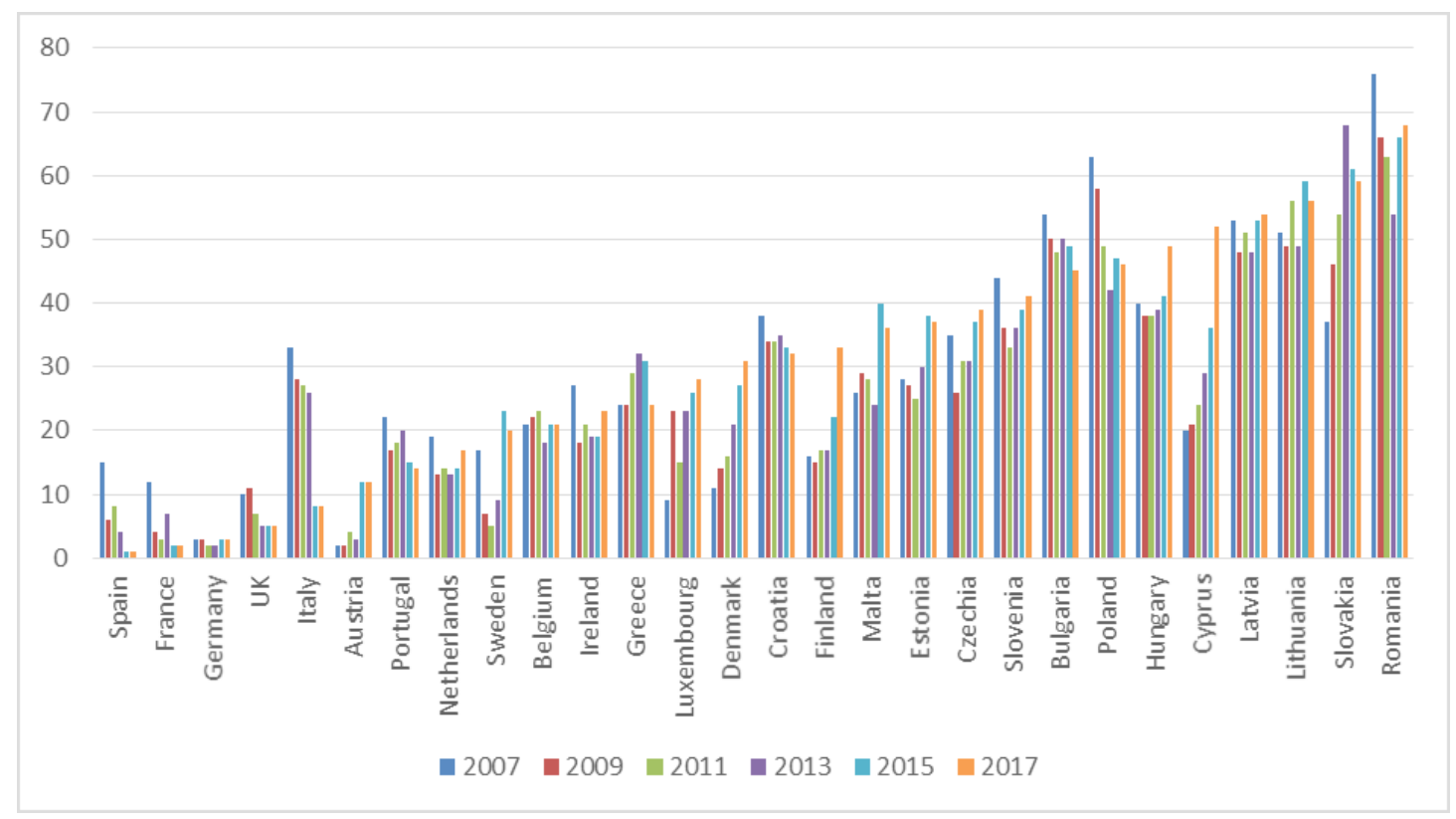

Figure 21: International competitiveness ranking evolution for EU-28

Sources: by author using TTCRs 


\begin{tabular}{|l|c|c|c|c|c|c|}
\hline geoltime & 2007 & 2009 & 2011 & 2013 & 2015 & 2017 \\
\hline Spain & 15 & 6 & 8 & 4 & 1 & 1 \\
\hline France & 12 & 4 & 3 & 7 & 2 & 2 \\
\hline Germany & 3 & 3 & 2 & 2 & 3 & 3 \\
\hline UK & 10 & 11 & 7 & 5 & 5 & 5 \\
\hline Italy & 33 & 28 & 27 & 26 & 8 & 8 \\
\hline Austria & 2 & 2 & 4 & 3 & 12 & 12 \\
\hline Portugal & 22 & 17 & 18 & 20 & 15 & 14 \\
\hline Netherlands & 19 & 13 & 14 & 13 & 14 & 17 \\
\hline Sweden & 17 & 7 & 5 & 9 & 23 & 20 \\
\hline Belgium & 21 & 22 & 23 & 18 & 21 & 21 \\
\hline Ireland & 27 & 18 & 21 & 19 & 19 & 23 \\
\hline Greece & 24 & 24 & 29 & 32 & 31 & 24 \\
\hline Luxembourg & 9 & 23 & 15 & 23 & 26 & 28 \\
\hline Denmark & 11 & 14 & 16 & 21 & 27 & 31 \\
\hline Croatia & 38 & 34 & 34 & 35 & 33 & 32 \\
\hline Finland & 16 & 15 & 17 & 17 & 22 & 33 \\
\hline Malta & 26 & 29 & 28 & 24 & 40 & 36 \\
\hline Estonia & 28 & 27 & 25 & 30 & 38 & 37 \\
\hline Czechia & 35 & 26 & 31 & 31 & 37 & 39 \\
\hline Slovenia & 44 & 36 & 33 & 36 & 39 & 41 \\
\hline Bulgaria & 54 & 50 & 48 & 50 & 49 & 45 \\
\hline Poland & 63 & 58 & 49 & 42 & 47 & 46 \\
\hline Hungary & 40 & 38 & 38 & 39 & 41 & 49 \\
\hline Cyprus & 20 & 21 & 24 & 29 & 36 & 52 \\
\hline Latvia & 53 & 48 & 51 & 48 & 53 & 54 \\
\hline Lithuania & 51 & 49 & 56 & 49 & 59 & 56 \\
\hline Slovakia & 37 & 46 & 54 & 68 & 61 & 59 \\
\hline Romania & 76 & 66 & 63 & 54 & 66 & 68 \\
\hline
\end{tabular}

Table 1: Travel \& Tourism Competitiveness Index for EU-28

Sources: by author using TTCRs

TTCI is built over 14 pillars: policy rules and regulations (prevalence for foreign ownership, property rights, business impact of rules on FDI, visa requirements, openness of bilateral Air Service Agreements, transparency of government policymaking, time required to start a business, cost to start a business), environmental sustainability (stringency of environmental regulation, enforcement of environmental regulation, sustainability of T\&T industry development, carbon dioxide emission, threatened species, environmental treaty ratification), safety and security (business cost of terrorism, reliability of police service, business cost of crime and violence, road traffic accidents), health and hygiene (physician density, access to improve sanitation, access to improve drinking water, hospital beds), prioritization of Travel \& Tourism (government prioritization of T\&T industry, T\&T government expenditure, effectiveness of marketing and branding, T\&T fair attendance), air transport infrastructure (quality of air transport infrastructure, availability seat kilometers domestic and international, departure per 1,000 population, airport density, number of operating airlines, international air transport network), ground transport infrastructure (quality of roads, quality of railroad infrastructure, quality of port infrastructure, quality of ground transport network, road density), tourism infrastructure (hotel rooms, presence of major car rental companies, ATMs accepting Visa cards), ICT infrastructure (extent of business Internet use, Internet users, telephone lines, broadband Internet subscribers, mobile telephone subscribers), price competitiveness in the T\&T industry (ticket 
taxes and airport charges, purchasing power parity, extent and effect of taxation, fuel price levels, hotel price index), human resources (primary education enrollment, secondary education enrolment, quality of the education system, local availability of research and training services, extent of staff training, hiring and firing practices, ease of hiring foreign labor, HIV prevalence, business impact of HIV/AIDS, life expectation), affinity for T\&T (tourism openness, attitude of population towards foreign visitors, extent of business trips recommended), natural resources (number of World Heritage sites, protected areas, quality of the natural environment, total known species), cultural resources (number of World Heritage cultural sites, sports stadiums, number of international fairs and exhibitions, creative industries exports).

The outlook for Travel \& Tourism Competitiveness Index for EU-28 by the $14^{\text {th }}$ main pillars (sub-indexes) and pillars of sub-indexes is presented in table 1. Romania is always on the final place. Spain registered a spectacular increase in scoring the world competitiveness, for its cultural resources (World Heritage sites), many international fairs and exhibitions, sport stadiums, tourism infrastructure.

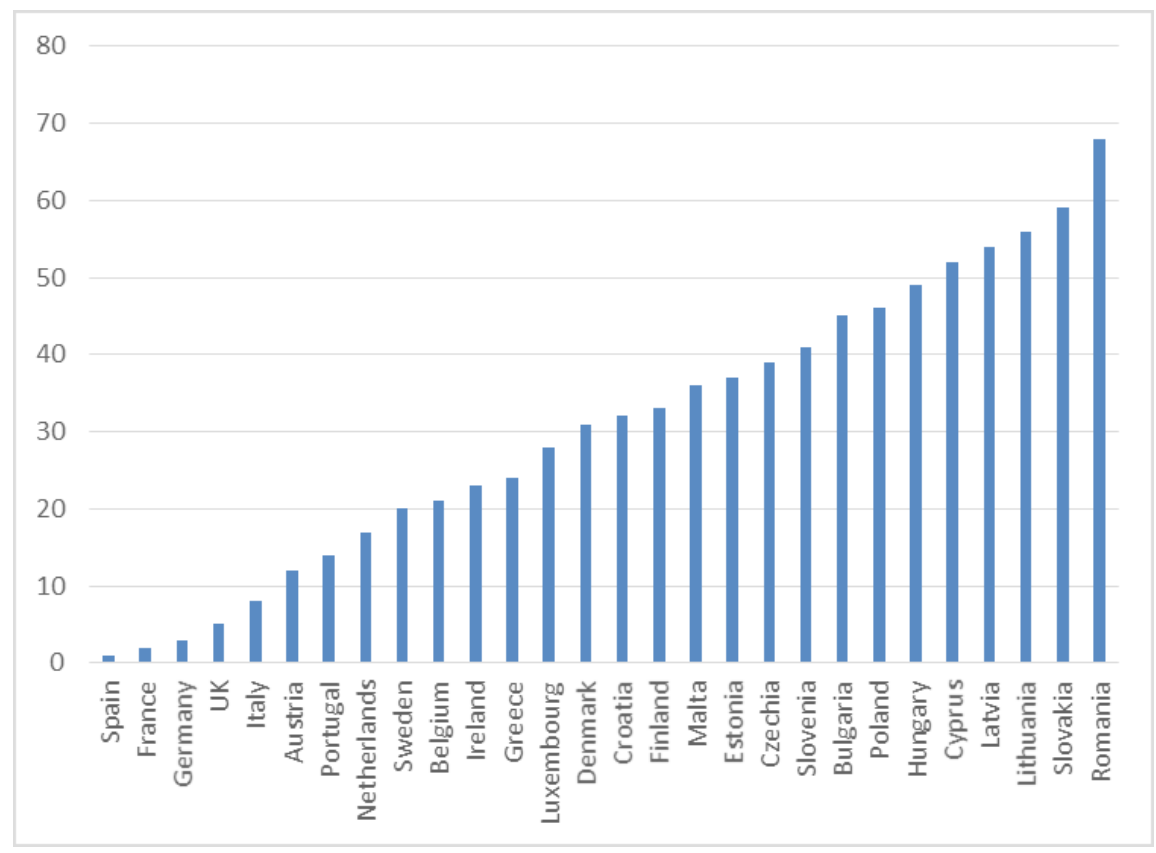

Figure 22: TTCI for EU-28 in 2017.

Source: The Travel \& Tourism Competitiveness Report 2017 [World Economic Forum]

In 2017 (figure 22) the first three places are occupied by EU-28 countries according to TTCI, the best performance has Spain, and Romania has the weakest performance. The most influenced factors responsible for the weak performance of Romania are considered to be associated with corruption and decision makers' policies.

\section{CONCLUSION}

The travel and tourism industry is a dynamic engine; the direct contribution of global tourism industry to the world global GDP recorded 3.2\% in 2017 and total contribution to global GDP was $10.4 \%$ and is expected to increase to $11,7 \%$ in 2028 ; it supports one in every ten jobs on the planet with $3.5 \%$ direct contribution to employment, with $2.8 \%$ total contribution to the employ- 
ment, and with $1 \%$ capital investment in the global GDP (World Travel \& Tourism Council). In the frame of EU-28 the results are almost the same: with $3.9 \%$ for direct contribution, $10.3 \%$ for total contribution to GDP, with $11.7 \%$ total contribution to the employment, and with 5.1\% capital investment in GDP, leisure spending (77.1\%), business $(22.9 \%)$, foreign visitors $(31.4 \%)$, domestic visitors $(68.6 \%)$.

From the present empirical and theoretical study, it is easy to notice that:

1. the weakest countries participating in tourism activity (for personal reasons for instance) are the weakest in GDP per capita and the performers in tourism participation are the performers in GDP per capita;

2. the weakest countries regarding the share of expenditure with research and development in the gross domestic product are the same with the less participation in tourism activity and with the less performances regarding the GDP per capita;

3. the weakest countries regarding the allocation in transport, telecommunication and other infrastructure from Government Budget Appropriation on Research and Development (GBAORD), even it is expressed in euro per habitant or in percentage of GDP, are the same with the weakest countries regarding the share of expenditure with research and development in the gross domestic product and with the less participation in tourism activity, and with the less performances regarding the GDP per capita;

4. the smallest index for the share of expenditure with R\&D in GDP is obtained by Latvia, Romania and Bulgaria, and the greatest index is obtained by Denmark and Finland;

5. the index of the accommodation establishments for 2012/2016 generally increased in all EU-28 countries;

6. the tourism activity is very high (Italy, Germany, Spain) but in almost 14 countries the figures are small;

7. there are big discrepancies between the European countries regarding the number of the persons employed in tourism entities;

8. there is consistent difference between the European countries regarding the evolution of the turnover per person employed in tourism entities;

9. the labour productivity is reduced in the most European countries;

10. the investment per person employed is reduced comparing with the best performance of United Kingdom;

11. the gross value added per employee (expressed in thousand euro) is very different through the European countries: the gap between the best performance (United Kingdom with 158 thousand euro) and the lowest performance (Romania with 10 thousand euro) is huge (15 times);

12. the first 10 places on the Travel \& Tourism Competitiveness Index are taken by five European Union countries. But, on the other hand, there is a country (Romania) placed after the halt of the international rankings on tourism and travel.

Solutions and recommendations by author:

1. to increase the GDP per capita (not economic growth) in order to increase the share of the tourism activities and expenses in total household income;

2. to increase the investment in research and development field and to rise the share of them in the total GDP (in million and in euro per capita);

3. to increase the allocation in transport, telecommunication and other infrastructure from Government Budget Appropriation on Research and Development (GBAORD), even it is expressed in euro per habitant or in percentage of GDP; 
4. to increase the accommodation establishment and the quality of the tourism services;

5. to improve the tourism infrastructure through investments;

6. to increase tourism activity in quantity but especially in quality;

7. to ensure proper qualified employees;

8. to realize more sales and turnover per person employed in tourism entities through offering a qualified service and diverse tourism products;

9. to realize an increase in the labour productivity;

10. to increase the investments per person employed;

11. to improve the corporate management in order to increase the value added per employee;

12. to improve the position on the tourism and travel international rankings following the issues raised by Tourism and Travel Council;

13. to improve the tourism marketing in the countries with less performances;

14. to increase the administration performances and to improve the good governance.

In the last period of time, the European tourism industry and service, from both qualitative and quantitative point of view, has increased. The market of the European Union tourism has developed comparing the huge potential and comparing other countries due to the natural and cultural richness, the tourism infrastructure, the environmental sustainability performance, business environment, international openness, the perception of safety despite the thin decrease of the security perception in Western and Southern Europe. Also, significant disparities among them still remain. All in all, Europe is the largest T\&T market.

On the other hand, the tourism industry is characterized by a dramatic level of overcapacity and rising number of insolvent hotels. To manage the issues currently dominating the global hotel sector, tourism management must refocus efforts on formulating effective operations analysis to optimize the productivity and profitability in an increasingly competitive tourism market. By that means, tourism may gradually have a greater share in economic sector having a huge potential but whose exploitation requires efficient management. The lack of accord regarding technique and economic solutions, the resistance of those elements makes themselves feel threatened by change and by uncertainty tied with the alternative solution' costs and benefits that are the main obstacles in integration of the specified objective. It is necessary to establish some strategies to approach unitarily the economic, social and environmental issues, changing or enforcing the values, knowledge, technologies and institutions [24].

The limitation of the empirical part consists in the availability of the data. Depending on this it is envisioned to approach in future research the empirical correlation between the expenditure with research and development and tourism industry results (as share in GDP, for instance), the tourism activity, the research and development investments, the education level and the GDP, as living level indicators. 


\section{REFERENCES}

[1] Glaesser, D. (2006) Crisis Management in the Tourism Industry, Elsevier Publisher.

[2] Lamb, R. (1984) Competitive Strategic Management, Prentice Hall, Inc., Englewood Cliffs, New Jersey.

[3] Dan, V. (1997) Strategii si structuri industriale competitive, Editura All Educational, Bucuresti

[4] Jaba, O. (1999) Analiza strategica a întreprinderii, Editura Sedcom Libris, Iasi.

[5] Poon, A. (1993) Tourism, Technology and Competitive Strategies, CAB International, UK, pp.370.

[6] Macmillan, H., Tampoe, M. (2000) Strategic management, Oxford University Press Inc., New York.

[7] Johnson G., Scholes K. (2002) Exploring corporate strategy, Ed. Prentice Hall.

[8] Russu, C. (1999) Management strategic, Editura All Beck, Bucuresti

[9] Danciu, V. (2004) Marketing strategic competitiveness, Ed. Economica, Bucuresti, pp. 30.

[10] Hunt, S. D., Morgan, R. M. (1995) The Comparative Advantage Theory of Competition, Journal of Marketing, Vol.59.

[11] Porter, M. (1984) Competitive Advantage: Creating and Sustaining Superior Performance, The Free Press, New York.

[12] Krugman, P. (1996) Making Sense of the Competitiveness Debate. Oxford Review of Economic Policy 12(3), pp.17-25.

[13] Krugman, P. (1990) The Age of Diminished Expectations. The MIT Press, Cambridge.

[14] Porter, M.E. (1990) The Competitive Advantage of Nations. The Free Press, New York.

[15] Siudek, T., Zawojska, A. (2014) Competitiveness in the Economic Concepts, Theories and Empirical Research, Oeconomia 13 (1), pp.91-108.

[16] Bobba, F., Langer, W., Pous, J.W. (1971) Bericht über die Wettbewerbsfähigkeit der Europäischen Gemeinschaft, Brussels.

[17] Barker, T., Köhler, J. (1998) Environmental Policy and Competitiveness. Environmental Policy Research Briefs 6, pp.1-12.

[18] Ajitabh, A., Momaya, K. (2004) Competitiveness of Firms: Review of Theory, Frameworks and Models. Singapore Management Review 26(1), pp.45-61.

[19] Chao-Hung, W., Li-Chang, H. (2010) The Infl16uence of Dynamic Capability on Performance in the High Technology Industry: The Moderating Roles of Governance and Competitive Posture. African Journal of Business Management 4(5), pp.562-577.

[20] Buckley, P.J., Pass, C.L., Prescott, K. (1988) Measures of International Competitiveness: A Critical Survey. Journal of Marketing Management 4(2), pp.175-200.

[21] Tyson D’Andrea, L. (1992) Who's Bashing Whom: Trade Conflict in High Technology Industries. Institute for International Economics, Washington, D.C.

[22] World Economic Forum, The Travel \& Tourism Competitiveness Report 2017 (TTCR 2017), available at https://www.weforum.org/reports/the-travel-tourism-competitiveness-report-2017, accessed 31.10.2018.

[23] World Travel \& Tourism Council, Travel \& Tourism Economic Impact 2018, European Union, report available at https://www.wttc.org/-/media/files/reports/economic-impact-research/regions-2018/europeanunion2018.pdf, accessed 11.11.2018.

[24] Groom, A.J.R., Taylor P. (1990) (editors). Frameworks for International Co-operation, Pinter Publishers, London. 